Original paper

\title{
Living with Landslides: Perceptions of Risk and Resilience in Far West Nepal
}

\author{
Juliette Genevieve Crescentia Martin ${ }^{1}$, Prakash Khadka ${ }^{1,2}$, Joanne Linnerooth-Bayer ${ }^{1}$, \\ Stefan Velev ${ }^{1}$, Caroline Russell ${ }^{3}$, Binod (Prasad) Parajuli ${ }^{4}$, Puja Shaky ${ }^{2}$, Sumit Vij ${ }^{5}$, and \\ Wei Liu ${ }^{1}$
}

Received: 27/02/2021 / Accepted: 27/09/2021 / Published online: 28/12/2021

\begin{abstract}
This study presents an analysis of risk and resilience perceptions in two villages of Far West Nepal, Sunkuda and Bajedi, located in the upper Karnali River Basin. The area has been affected by deep-seated and shallow landslides, which have had a devastating impact on many rural lives and livelihoods. While both villages are exposed to landslides, Bajedi is situated in a higher risk zone. Using structured surveys, semi-structured interviews and insights from stakeholder workshops, the risk and resilience perceptions of household residents of the two villages are elicited. The objectives of the study are 1) to understand how residents perceive their risk and resilience to landslides, and 2) to provide evidence and insights on the factors that influence risk perception. Results show that landslides are perceived as an existential risk in both villages, although risks are perceived as more serious in Bajedi. The higher risk perception in Bajedi is shown to be mainly driven by households' ability to cope, including their energy sources, whether they know whom to call in case of a landslides, as well as household savings and income sources. In Sunkuda, risk perception is shown to be influenced by households' access to and status of community forests, expenditure on medication, the seasonality and types of water sources, and ethnicity. In both villages, additional drivers of risk perception include households' social networks, their perceived triggers of landslides, their outstanding loans, and who collects the water. The results demonstrate the interconnectedness of risk perception and indicators of resilience. By elucidating the risk perception of Sunkuda and Bajedi, this study has important implications for local risk management strategies and policies.
\end{abstract}

Keywords: Risk perception, Resilience, Landslide, Boosted Regression Trees, Five Capitals

\footnotetext{
1 Equity and Justice Research Group, International Institute for Applied Systems Analysis (IIASA)

* Corresponding author email: Juliette Martin, martinj@iiasa.ac.at

2 Climate and Resilience, Practical Action Consulting South Asia

3 Department of Geography, University of Birmingham

4 Department of Geography, University of Durham

5 Public Administration and Policy Group, Wageningen University \& Research
} 


\section{INTRODUCTION}

In many regions of the world, landslides represent a major risk to human lives, property, and resources. This is particularly true for Nepal where the world's highest mountain range, the Himalayas, is located. Petley et al. (2007) observed an upward trend in occurrences of landslides in Nepal since 1978, with Nepal accounting for $10 \%$ of all fatal landslides globally (Froude and Petley 2018). In Nepal, landslides are driven by a complex combination of factors, including seasonality, seismic activity, climate change (e.g., heavy rainfall events) and other anthropogenic stressors (e.g., road construction, land conversion) (McAdoo et al. 2018; Petley et al. 2007).

Many mountain areas in Nepal are physically and economically marginalized (Department for International Development 2013). In Far Western Nepal, where poverty, food insecurity, and social inequity are severe, many of the most productive members of rural households opt to migrate for better economic opportunities (Thieme 2003). Thus, land-use change to connect rural communities with outer markets is considered as one of the drivers of landslides in rural Nepal (Froude and Petley 2018; McAdoo et al. 2018; Sudmeier-rieux et al. 2019)

Until recently, landslide risk had received little attention from Nepal's policymakers due to budgetary restrictions, underreporting of associated losses, siloed institutions with poor interdepartmental collaboration, and competing disaster paradigms that focus largely on disaster response rather than preparedness (Vij et al. 2020). Thus, mountain communities and households are typically left to devise their own strategies to mitigate and enhance their resilience to landslide risk.

Understanding how members of communities perceive their risk and resilience to landslides is critical for developing effective DRR and resilience-building action plans. According to the United Nations Development Programme (UNDP 2015:7), disaster risk is defined as "the probability of harmful consequences - casualties, damaged property, lost livelihoods, disrupted economic activity, and damage to the environment - resulting from interactions between natural or human-induced hazards and vulnerable conditions". This is conventionally expressed as a combination of hazard likelihood, exposure, and vulnerability (IPCC 2020). For the purpose of this study, risk is characterized as a combination of the likelihood of a landslide event and its impact.

Risk perception is a subjective judgment that people make about the characteristics of hazards and the severity of their impacts (Sjöberg et al. 2004). A basic premise is that risk perception is inherently subjective due to the complexity of human response to the hazards they perceive (Slovic 1980). There is substantial literature on the concept and measurement of risk perception from psychological, anthropological, and sociological perspectives (HernándezMoreno and Alcántara-Ayala 2017). Slovic et al. (1980) argue that risk perception is influenced by the nature of the risk, in particular the risk's voluntariness, controllability, familiarity, immediacy of consequences, and threat to future generations. The perception of risk has also 
been shown to differ with the proximity to a hazard (Aboagye, Dari, and Koomson 2013), previous experience (Hernández-Moreno and Alcántara-Ayala 2017), demographic characteristics including socio-economic status (Peacock, Brody, and Highfield 2005), as well as individual worldviews (Douglas 1979). Importantly, in highly vulnerable communities the impacts of landslides and other hazards depend strongly on the ability and capacity of communities to recover their health, property, and livelihoods in response to the hazard. Risk perception is closely interrelated with resilience.

Resilience is generally defined as the capacity of individuals or groups to cope, adapt, and transform in the face of uncertainty or shocks through learning from the past, planning for the future, or reorganization in the face of uncertainty (de Weijer and McCandless 2015). Resilience is composed of many interlinked dimensions, ranging from tangible economic factors, such as wealth and livelihood, to other household assets, including human, natural, physical and socio-political capital (Keating et al. 2017). In light of this complexity, numerous resilience measurement approaches have recently emerged (Cai et al. 2018; Schipper and Langston 2015; Sharifi and Yamagata 2016). The Five Capitals (5C) framework was developed as part of the Sustainable Livelihoods Framework (DFID 1999) for ensuring disaster resilience. The framework is based on five 'capitals' or dimensions: human (human skills, knowledge and health), socio-political (social and institutional networks), natural (natural resources and other ecosystem services), physical (infrastructure and services), and financial (economic resources such as savings, remittances, loans) (Harris 2020; Keating et al. 2017). The 'capitals' terminology is commonly used to describe the static dimension of resilience and typically calculated as the state of a community before and after a disaster (Serfilippi and Ramnath 2018). A further commonly used framework is proposed by Béné et al. (2012), who argue that resilience emerges as the result of three capacities: absorptive, adaptive, and transformative, each leading to an outcome of persistence, incremental adjustment, or transformational responses, respectively.

Therefore, considering how and why households feel 'resilient' to landslides is not only key to developing resilience strategies that are tailored to the local needs of stakeholders, but adds insight into the complex layers of risk perception. Again, risk and resilience perception are intricately linked. Landslide risk perception has been investigated in communities in South East Asia (He and Zhai 2015; Ho et al. 2008), Europe (Antronico et al. 2020; Calvello et al. 2016), South America (Nathan 2008; Tobin et al. 2011), and North America (Butler and DeChano 2012; Peacock et al. 2005); yet little is known about the influences of landslide risk perception in Nepal. The purpose of this study is twofold: A first aim is to understand how residents in two highly exposed villages in Far West Nepal (Sunkuda and Bajedi) perceive their risk and resilience to landslides (Section 4.1). A second aim is to identify those factors that contribute to the resident's perception of risk (Section 4.2). Those factors related to resilience are grouped according to three composite capitals: financial, natural-physical, and socio-political (Sections 4.2.1-4.2.4). Since the two villages are different in terms of their risk exposure and resilience, we also draw comparative insights. By elucidating the underlying factors influencing risk and 
resilience perception, the study draws conclusions for local risk management strategies and policies.

\section{STUDY SITES}

Two mountain villages were chosen for this study: Sunkuda, a village in Bithadchir Rural Municipality of Bajhang District, and Bajedi, a village in Budhiganga Municipality of Bajura District. There are about 606 households consisting of 4000 residents in Bajedi and 329 households with 1645 residents in Sunkuda. Both sites are located in the upper Karnali River Basin in west Nepal (figure 1), an area affected by a complex interplay of hazards, including landslides, floods, and earthquakes. The two study sites are subject to deep-seated slides and more commonly to shallow slides that have the greatest impact on rural livelihoods (SudmeierRieux et al. 2012). A major deep-seated slide devasted parts of Bajedi in 2013 and 2019, causing river blockages through landslide debris, and as recently as July, 2020, six households were displaced and ten families evacuated due to a rainfall-triggered slide (RSS 2020; Singh 2018). The last major landslide event in Sunkuda took place almost 50 years ago (Cieslik et al. 2019). Both locations experience frequent seasonal shallow soil (Sunkuda) or rock (Bajedi) slides.

The impact of landslides in the study areas includes loss of lives, livelihoods, assets, destruction of agricultural land, and damage to drinking water sources and irrigation canals. These impacts are expected to intensify due to climate change, unsustainable land-use practices, and poorly regulated development (Sudmeier-rieux et al. 2019; Vuillez et al. 2018). The expanding area affected by landslides in the study sites has led to diminished or complete loss of agricultural land owned by individual households, depriving these communities of their primary source of livelihood.

Sunkuda and Bajedi villages differ in several aspects. Sunkuda village shows signs of greater development and structural investment. It is connected by the Jay Prithvi Highway (a tarmac road) making the village accessible in case of a disaster. While households in Sunkuda rely on solar power for electricity, electrical wires currently run through the village to the rural municipality, and there is a hydropower plant under development in the region. Furthermore, Sunkuda benefits from the presence of active non-governmental organizations (NGO), e.g., the Red Cross, Practical Action and Mercy Corps, each working in collaboration with communitybased organizations. With support from NGOs, households in Sunkuda are involved in livelihood diversification measures, such as vegetable farming, and have set up an informal banking system through which households can take out loans and place savings.

Bajedi, in contrast, is more remote and accessible only by foot or mud tracks that are mostly unsuitable for large vehicles. Households in Bajedi receive little help from development projects or NGOs. With a greater proportion of mud houses compared to Sunkuda, Bajedi is 
particularly vulnerable to landslides. Moreover, households in Bajedi are also subject to landslide damage to their agricultural land. The soil frequently exhibits cracks that can eventually lead to slope collapse during heavy rainfall. Households in Bajedi have attempted a range of landslide risk management measures, such as revegetation, restriction of open grazing, channelling excess water outflows from agricultural land, and establishing temporary shelters during the monsoon (Cieslik et al. 2019). The response, however, is less organised than in Sunkuda.

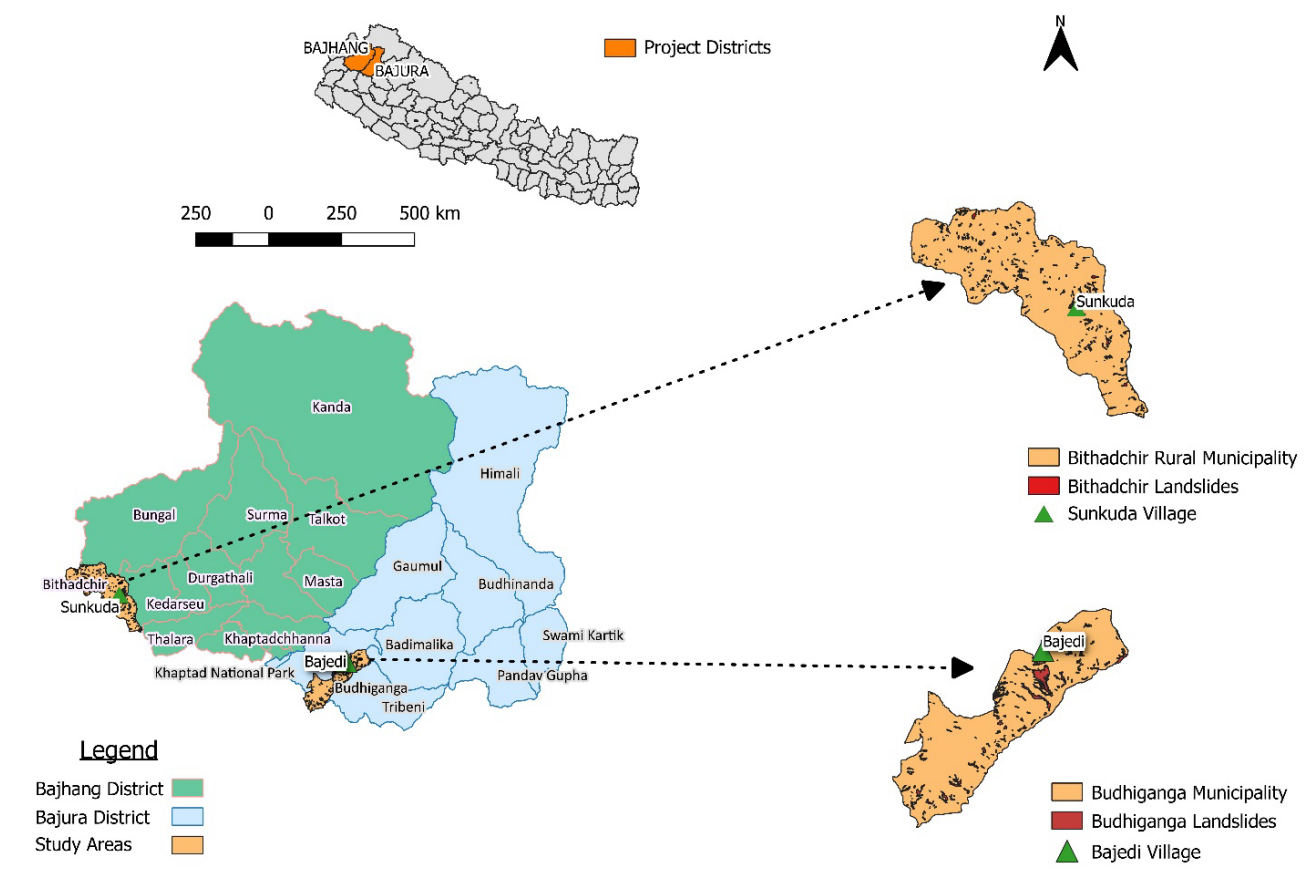

Figure 1. Study areas of Far West Nepal. Source (A. Muñoz-Torrero Manchado, S. Allen 2021)

\section{METHODS}

\subsection{Household Survey, interviews, and workshops}

Structured household surveys were carried out in Sunkuda and Bajedi during March and May 2019. The survey questions (Appendix 1) were designed to elicit views of landslide risk and resilience at the household level. The survey was organized according to six main categories: 1) general demographic data; 2) perception of risk and resilience; 3) household assets; 4) household livelihoods, finances, and hazards; 5) community services 6) risk preparedness and responses. A total of 193 households were included in the study, of which 72 households are located in Sunkuda village and 121 households in Bajedi village. The household survey includes seven statement entries on landslide risk and resilience perception shown in table 1. The responses are measured on a five-point Likert scale $(1=$ Strongly Agree, $2=$ Agree, 3 = No Opinion, 4 = Disagree, 5 = Strongly Disagree). 
Table 1. Statement entries on landslide risk perception and subjective resilience

\begin{tabular}{|l|l|}
\hline Risk indicators & Statements \\
\hline Fear & I am worried about the danger of landslides in my region. \\
\hline Impact & $\begin{array}{l}\text { Another landslide would have severe consequences for my } \\
\text { household. }\end{array}$ \\
\hline Likelihood & $\begin{array}{l}\text { My household and land are located on or near a slope that has a } \\
\text { strong landslide hazard potential. }\end{array}$ \\
\hline Future risk & $\begin{array}{l}\text { The risk of landslides in my region will increase in the future, } \\
\text { i.e., more frequent and/or more severe. }\end{array}$ \\
\hline Resilience indicators & $\begin{array}{l}\text { Considering the last major landslide event in my area, if a similar } \\
\text { landslide had recently occurred, my household could cope with } \\
\text { it and fully recover within six months. }\end{array}$ \\
\hline Coping capacity & $\begin{array}{l}\text { If landslides were to become more frequent and severe in the } \\
\text { future, my household can adapt to the threats and survive, for } \\
\text { example by diversifying our livelihood. }\end{array}$ \\
\hline Adaptive Capacity & $\begin{array}{l}\text { If landslides were to become more frequent and/or severe in the } \\
\text { future, my household can transform its way of living, e.g., by } \\
\text { migrating out. }\end{array}$ \\
\hline $\begin{array}{l}\text { Transformative } \\
\text { Capacity }\end{array}$ &
\end{tabular}

Recent literature and experience have emphasized the importance of the five capitals (5C) framework, which provides greater richness of data about communities' sources of resilience than any single metric (Keating et al. 2017). For this reason, the 5 Capitals (5C) framework (DFID 1999) was used as the guiding structure to classify risk perception drivers. The 5Cs consist of Socio-cultural, Human, Physical, Natural and Financial Capitals. Recognizing the use of this framework for capturing the multidimensional nature of risk and resilience perception, the survey was structured around the 5C framework, which will guide the discussion of the risk perception results. It additionally includes indicators of risk perception based on previous studies (Hernández-Moreno and Alcántara-Ayala 2017; Jones 2018; Jones and Tanner 2017; Liu et al. 2018). Respondents' key demographics are presented in Appendix 2 .

Household survey data were supplemented by semi-structured interview data with households and key informants (local political leaders and community elders) $(\mathrm{N}=19)$, and with field observations conducted throughout multiple site visits during 2018-2020. Additionally, a series of stakeholder workshops and consultations on emerging governance issues were held in 2018 at the municipal level. These workshops involved discussion groups and brought together teachers, principal of the school, red cross officials and elected officials $(\mathrm{N}=71)$. Workshop reports can be found in the Supplementary Materials. 


\subsection{Statistical analysis}

The statistical analysis of the household survey data is based on boosted regression trees (BRTs) (Gelman and Hill 2006). This approach was chosen because the assumptions underlying alternative approaches, such as linear, generalized linear, and nonlinear regression models, are violated by the survey data, including linearity, independence between independent variables and homogeneity. By being semi non-parametric, BRTs can accommodate complex nonlinear relationships and missing data. As their name suggests, BRTs are composed of a series of regression trees that describe the relationship between the dependent and independent variables using recursive binary splits and gradient boosting (an adaptive approach used to aggregate simple models to improve predictive performance). As such, the predictive performance of BRTs is often superior to traditional modelling methods (see Elith et al. 2008).

Data are clustered by village (Sunkuda and Bajedi) to account for the different risk and resilience profiles of the villages, for which two separate models are calculated. As the BRT method is non-parametric, i.e., it does not assume a normal data distribution, we measure the influence of a variable influence by its contribution to overall Mean Squared Error (MSE) variability. The completed BRTs have an out-of-sample MSE of 0.21 and 0.15 for Sunkuda and Bajedi, respectively. More information on these methods is provided in the supplementary materials.

\section{RESULTS AND DISCUSSION}

\subsection{Perceptions of risk and resilience in Sunkuda and Bajedi}

An overview of responses to the seven statement entries on landslide risk and resilience perception (table 1) by the 193 respondents is illustrated in figures 2 and 3. Concerning risk perception, the results (figure 2) show that almost all respondents in Bajedi and Sunkuda fear landslides (slightly more strongly in Bajedi), and $88 \%$ and $69 \%$ of respondents in Bajedi and Sunkuda, respectively, believe that future events would have fatal consequences for their households. The heightened concern in Bajedi is not surprising given the greater number of communities (90\% versus $66 \%$ in Sunkuda) reporting ('strongly agreeing' or 'agreeing') that they live near slopes with high landslide potential. Finally, respondents in both villages $(96 \%$ and 91\%) 'strongly agree' or 'agree' that landslide risk will increase in the future. Interviews carried out in the region supported and extended these results, namely that increasingly sporadic and heavy rainfall was considered a main trigger of landslides in Bajedi, and road construction and weak geology were considered main triggers in Sunkuda.

As shown in figure 3, respondents in both villages exhibit similar perceptions of their household's resilience, as evidenced by their responses to questions on their coping, adaptive and transformative capacity. Respondents in Bajedi (91\%) and Sunkuda (66\%) reported that if they were exposed to another landslide, they would not be capable of fully recovering 
('strongly agreed' or 'agreed'); 80\% (Bajedi) and 69\% (Sunkuda) reported that they could not fully adapt, e.g., by changing their livelihoods ('strongly agreed' or 'agreed'); and 72\% (Bajedi) and 78\% (Sunkuda) that they would not be able to transform their lives, e.g., by migrating to somewhere safer.

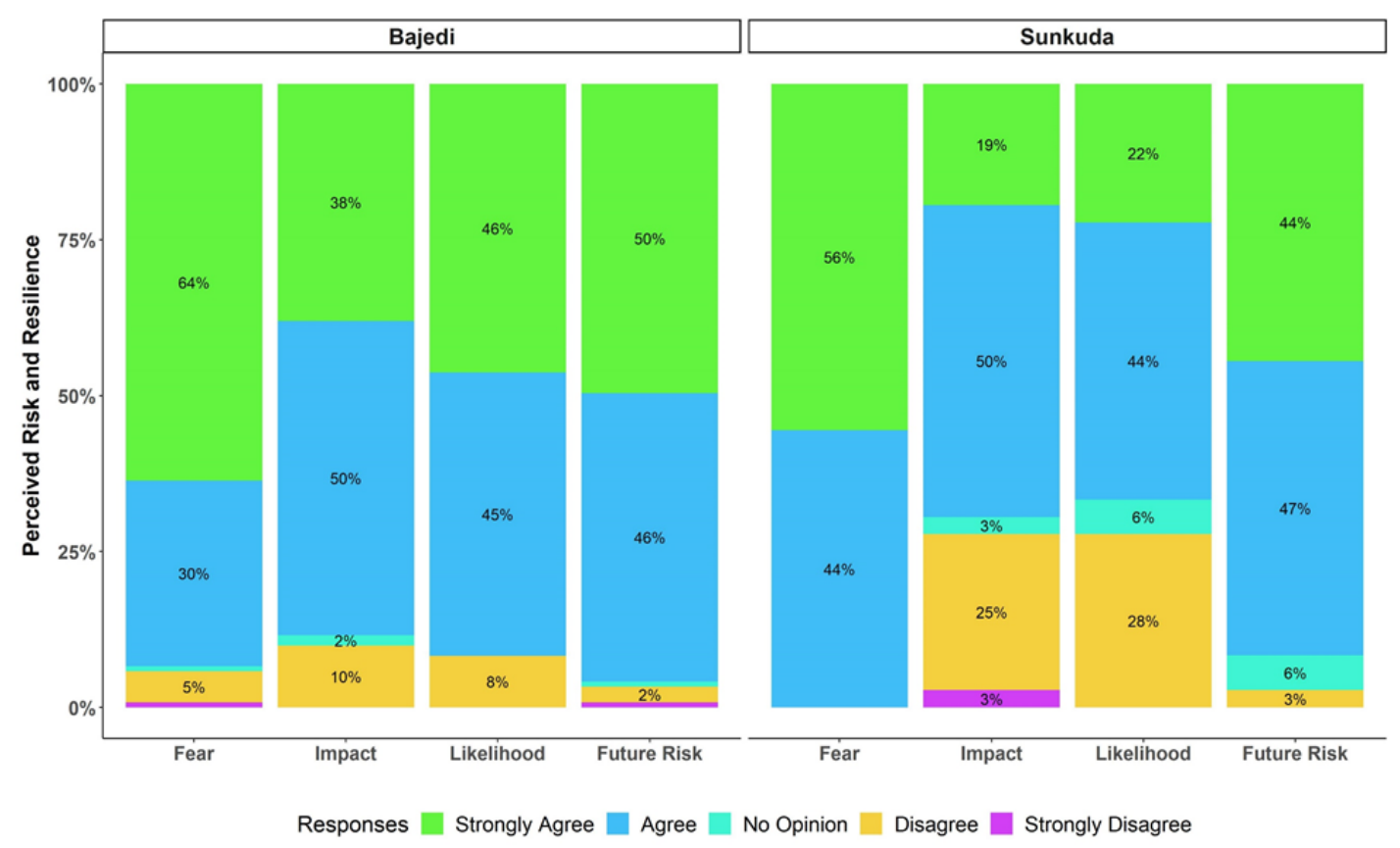

Figure 2. Responses to the four statements concerning risk perception in Bajedi (left) and Sunkuda (right)

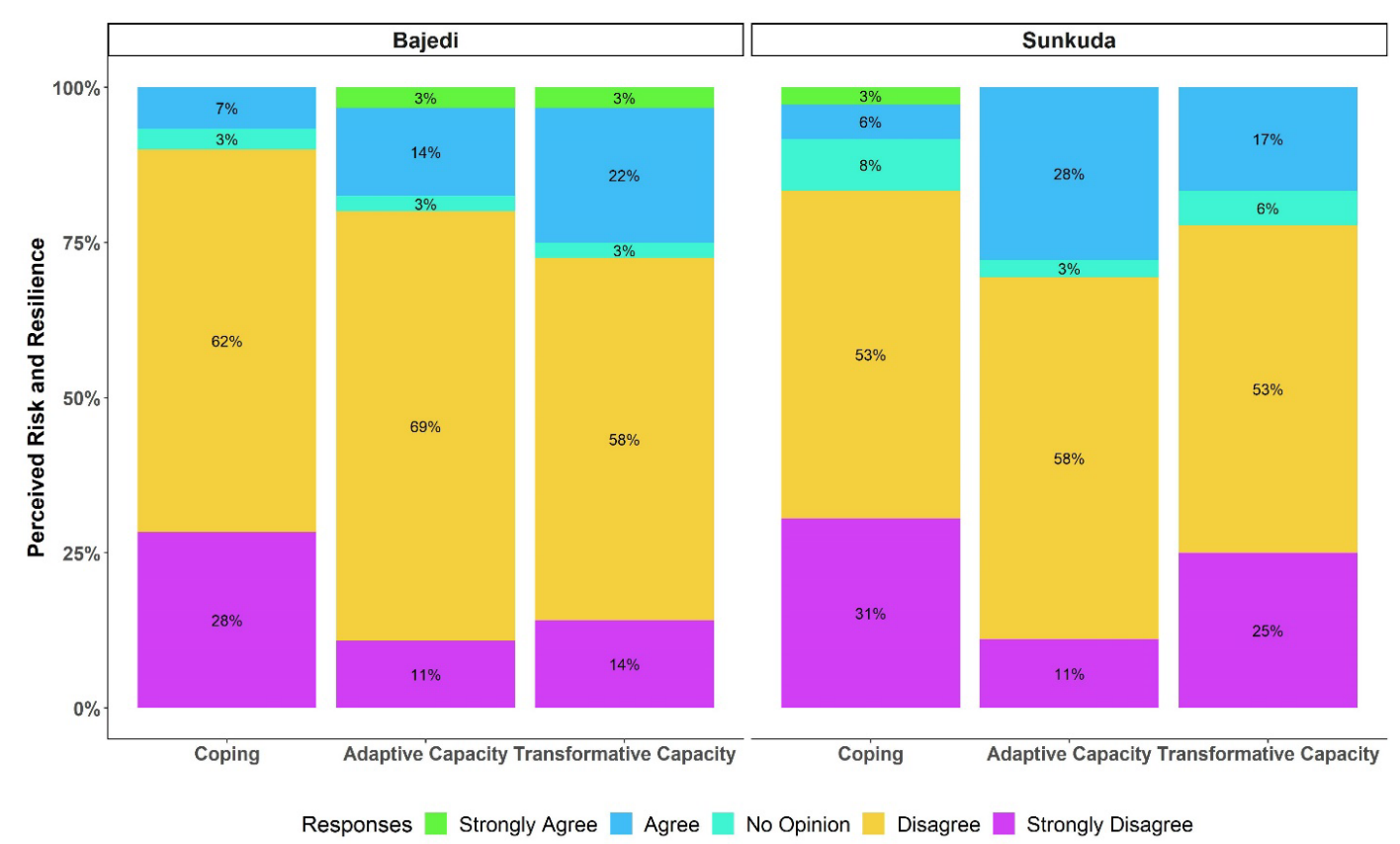

Figure 3. Responses to the three statements concerning resilience perception in Bajedi (left) and Sunkuda (right) 
The results provide strong evidence that landslides are perceived as a major and worsening, even existential, risk by almost all respondents in the surveyed households. The results also show that an overwhelming majority of respondents view their resilience in terms of their coping, adaptive and transformative capacity as low. Perceived risk indicators are somewhat higher in Bajedi, which has suffered more extreme landslides in the recent past.

\subsection{Drivers of risk perception}

This section delves more deeply into the factors influencing risk perception at the household level in Sunkuda and Bajedi. For this purpose, 'risk perception' is specified as a compound dependent variable composed of two (of the four) aspects of risk perception shown in table 1, namely the perceived impact of a landslide event and its perceived likelihood. This is consistent with the definition of risk discussed in section 1. The geometric mean of the likelihood and impact variables is calculated, where lower values indicate lower perceived risk and higher values indicate higher perceived risk on a 5-point Likert scale. Figure 4 shows the distribution of the computed risk perception variable in each village.

Figure 4 confirms earlier results by once more highlighting a higher perceived risk in Bajedi, whereas risk perception is more evenly distributed in Sunkuda. The survey variables that exhibit the greatest influence on risk perception in Bajedi and Sunkuda are extracted using Boosted Regression Trees (BRTs). A description of each independent variable is provided in table 2.
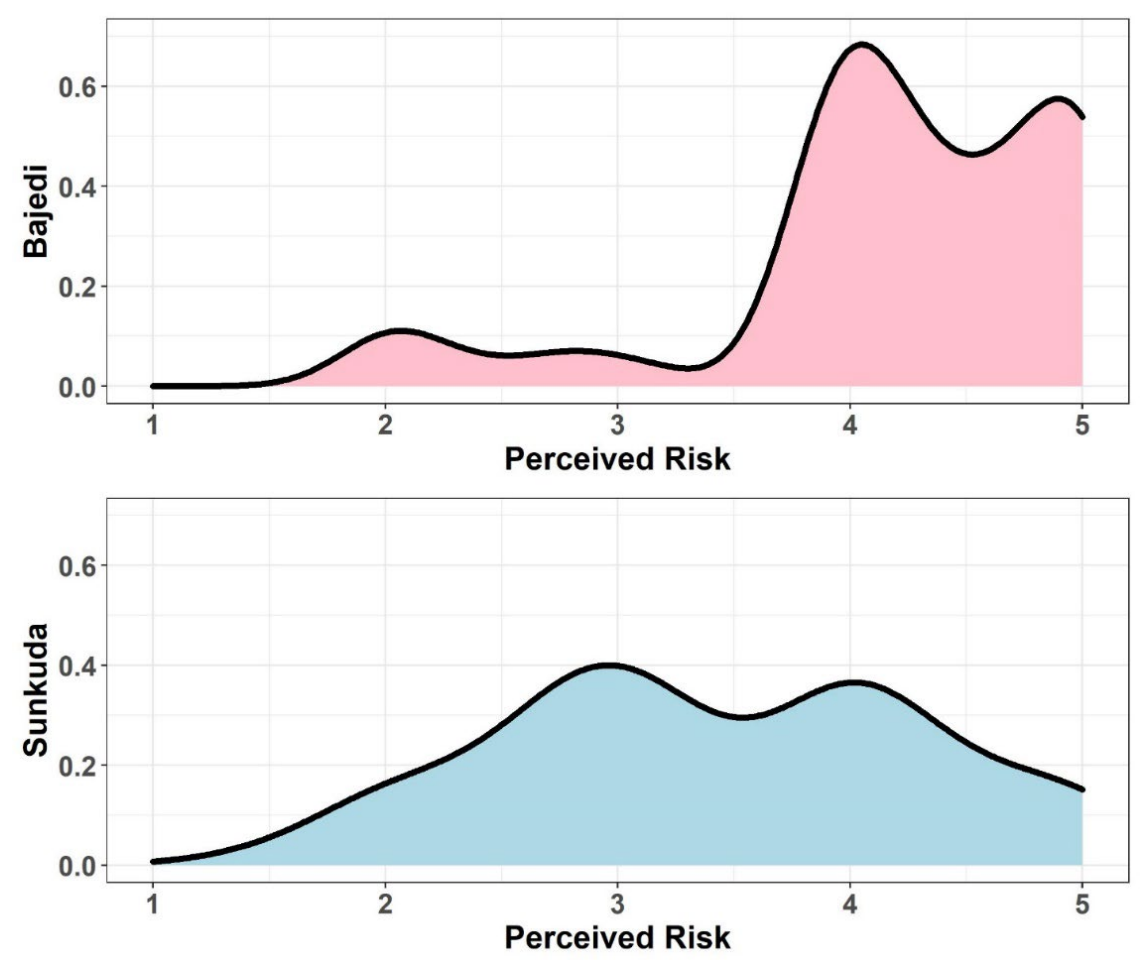

Figure 4. Kernel density plots of risk perception in Bajedi (top) and Sunkuda (bottom) 


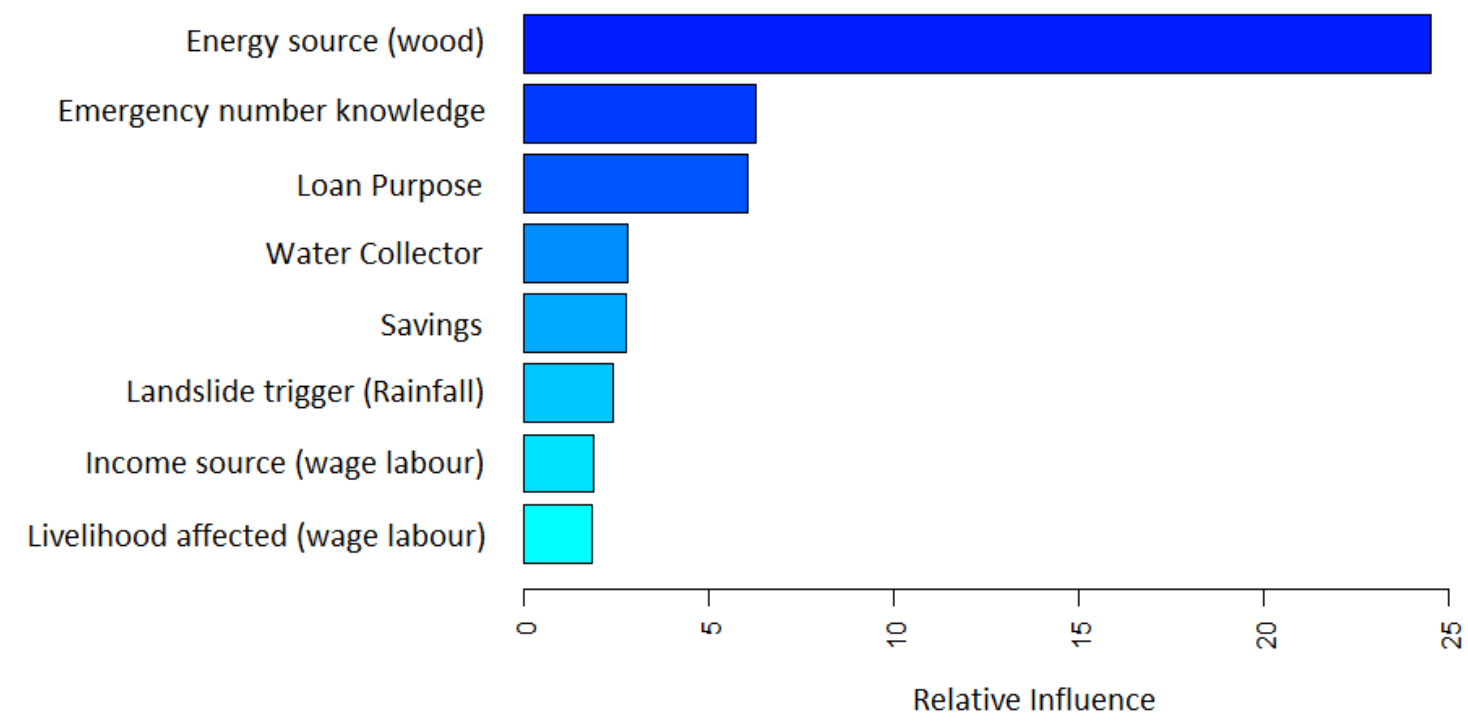

Figure 5. Bar plot of the variables having the most influence on risk perception in Bajedi

Figure 5 shows the main drivers of risk perception in Bajedi, which include mainly factors relating to the resilience of the households. Foremost is the household's energy source. Drivers with less but still important influence include knowledge of an emergency number, outstanding loans (depending on their purpose), the household member collecting water, and household savings. Interestingly, the single explanatory variable relating directly to the hazard itself is the landslide rainfall trigger.

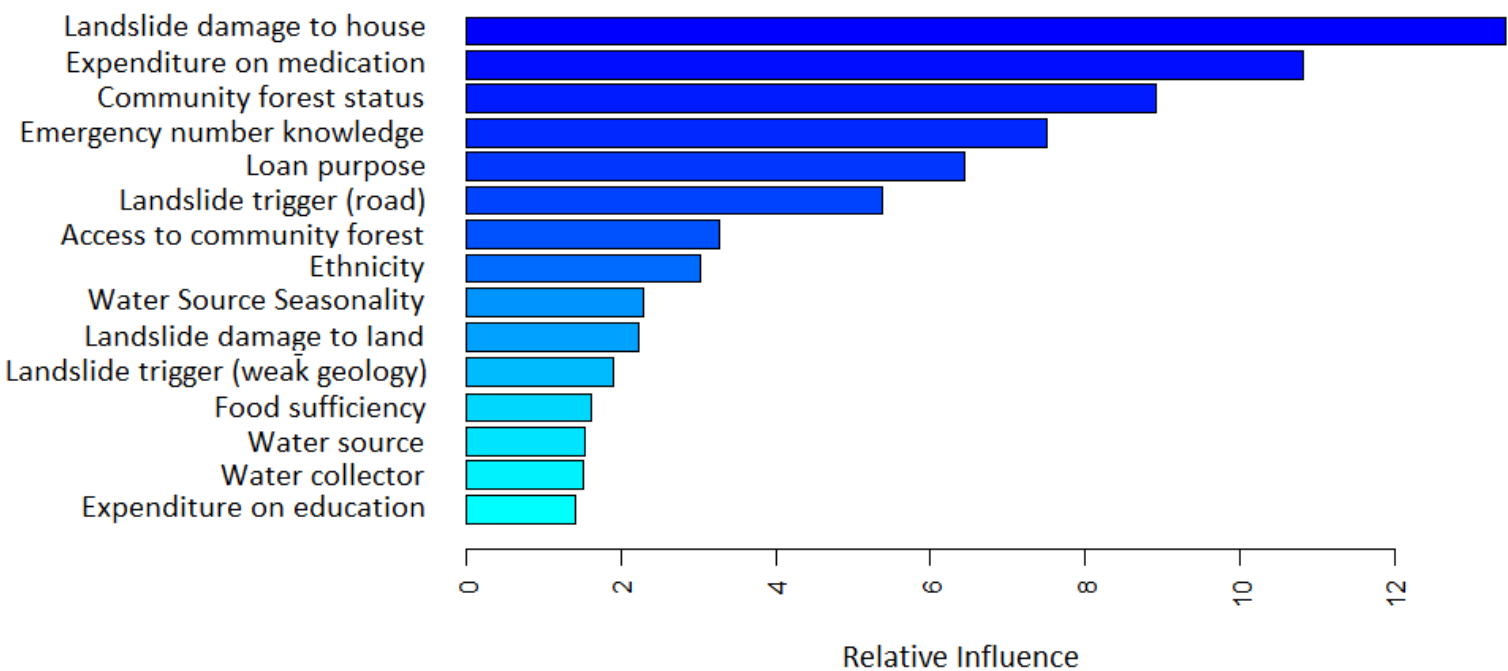

Figure 6. Bar plot of the variables having the most influence on risk perception in Sunkuda 
Table 2. Description of the variables driving risk perception

\begin{tabular}{|c|c|}
\hline Variables & Corresponding survey question \\
\hline Energy source & Q 5.2) Please rank your main energy sources \\
\hline Emergency number knowledge & $\begin{array}{l}\text { Q 6.5) Do household members know which number to call } \\
\text { in case of a landslide? }\end{array}$ \\
\hline Loan purpose & $\begin{array}{l}\text { Q 4.14) In the past } 10 \text { years, has your household taken out a } \\
\text { loan? For what purpose? }\end{array}$ \\
\hline Water collector & Q 5.7) Who mainly collects water for the household? \\
\hline Savings & $\begin{array}{l}\text { Q 4.12) Does your household have enough savings or other } \\
\text { assets to enable all household members to survive in the } \\
\text { event of a landslide? }\end{array}$ \\
\hline Landslide trigger & $\begin{array}{l}\text { Q 4.5) Which of the followings do you think are the major } \\
\text { contributors to landslide hazards in the past } 10 \text { years? }\end{array}$ \\
\hline Income source & $\begin{array}{l}\text { Q 3.4) Please rank the following income sources in terms } \\
\text { of their relative share of your total income. }\end{array}$ \\
\hline Livelihood affected & $\begin{array}{l}\text { Q 4.9) When landslides occur, how are your livelihood } \\
\text { activities affected? }\end{array}$ \\
\hline Landslide damage to house & $\begin{array}{l}\text { Q 4.6) Over the last } 10 \text { years was your house affected by } \\
\text { landslides? }\end{array}$ \\
\hline $\begin{array}{l}\text { Expenditure (on medication, on } \\
\text { education) }\end{array}$ & $\begin{array}{l}\text { Q 3.4) Please rank your annual expenditures in the last } 2 \\
\text { years }\end{array}$ \\
\hline Community forest status & $\begin{array}{l}\text { Q 5.25) What is the status of community forest compared } \\
\text { to non-community forest: better; similar; or worse? }\end{array}$ \\
\hline Access to community forest & $\begin{array}{l}\text { Q 5.22) Does your household have access to community } \\
\text { forest? }\end{array}$ \\
\hline Ethnicity & Q 1.1) What is your household's ethnicity? \\
\hline Water source seasonality & Q 5.5) Does your water source change seasonally? \\
\hline Landslide damage to land & $\begin{array}{l}\text { Q 4.8) Over the last } 10 \text { years, has your land been affected } \\
\text { by landslides? }\end{array}$ \\
\hline Food sufficiency & $\begin{array}{l}\text { Q 4.3) Generally, in 2017-2018 how many months of food } \\
\text { can you produce from your own fields per annum? }\end{array}$ \\
\hline Water source & Q 5.4) Where do you obtain your drinking water? \\
\hline
\end{tabular}

A contrasting and more multi-faceted picture emerge in Sunkuda. As shown in figure 6, the most influential factor on risk perception, not surprisingly, is related to the household's risk exposure, namely whether the house has been damaged by a landslide in the preceding ten years. Other risk-related factors include landslide triggers and damage to land. The most influential resilience-related explanatory variables include the household's expenditure on 
medication, the community forest status, knowledge of the emergency number and household loans (depending on their purpose)

A striking observation from the analysis is the extent to which risk perception is related to how the respondents view their household's coping, adaptive and transformative capacity, or resilience. In Bajedi, all significant risk perception drivers are related to resilience and not to the hazard likelihood or exposure. This is not the case in Sunkuda, where, consistent with risk perception literature (Bustillos Ardaya, Evers, and Ribbe 2017; Damm et al. 2013), hazard and exposure, including past landslide damage to the house and land, play a significant role. Indeed, in Sunkuda, a respondent's house having been damaged by a landslide in the last ten years is the most important factor increasing risk perception. Yet, even in Sunkuda indicators of resilience are important explanatory factors. The analysis hence highlights the strong links between risk, resilience, and vulnerability. Although these concepts are well defined in literature, there is no reasonable consensus on their overlap and the nature of their relationships (Serfilippi and Ramnath 2018).

In what follows, we explore the role of resilience in explaining risk perception in Bajedi and Sunkuda. For this, we organize the survey results according to the capital framework (DFID 1999) by grouping the explanatory variables into four (not five) composite capitals: financial, natural-physical, social-political and human. We draw on the survey results plus interviews, workshops and focus groups held in the region.

\subsubsection{Financial capital}

In Sunkuda and Bajedi, a majority of surveyed households (53\%) are engaged in two or more economic activities, mostly combining subsistence farming with occasional wage labour although paid jobs are in short supply in the study areas (Cieslik et al. 2019). Agriculture is increasingly at risk from earthquakes, landslides, and other climate-related hazards, and hardly provides a subsistence for most households. This has led to increasing out migration and dependence on remittances, not only in the studied villages, but throughout Nepal (Gartaula, Niehof, and Visser 2012).

Lacking insurance, vulnerable households in Nepal and across the developing world have traditionally financed post-disaster recovery with a combination of savings and credit, informal kinship arrangements, government relief and international donor support (Linnerooth-bayer et al. 2019). As illustrated in figures 5 and 6, financial factors are important driving forces in household respondents' risk perception. Indeed, three out of the eight most influential variables are related to financial capital in Bajedi, and three out of 15 in Sunkuda, highlighting the greater financial hardship faced by households in Bajedi. Respondents from households with meagre if any savings (figure 7), outstanding and past loans (figure 8) and especially loans for house repairs or medication, and insecure income sources, feel themselves to be more at risk from landslides. 
Savings have been shown to represent key strategies at household level to cope with disaster risk (Ahmad and Afzal 2020; Berman, Quinn, and Paavola 2015). Savings can take the form of cash or bank deposits, as well as stockpiles of food, grains, seeds, and marketable assets, such as livestock, which serve to smooth consumption during crises. Household savings in Bajedi and Sunkuda mostly take the form of livestock and their sale, including food, manure, and cash income (e.g., from selling milk). The loss of productive assets after a disaster is a major factor trapping poor households in poverty (Barnett, Barrett, and Skees 2008; Linnerooth-Bayer and Suarez 2011). It is striking that most surveyed households report savings that can assure their survival for only two days ( $3 \%$ of respondents) to one month $(58 \%$ of respondents), and very few households had savings for more than one month $(\mathrm{N}=15$, or $13 \%)$. Figure 7 shows that generally in Bajedi the greater the household's savings, the less the respondent felt at risk from landslides. This trend was less clear for households with no savings, which exhibit a larger data spread. These results confirm the importance of sufficient financial assets as means for households to feel less at risk.

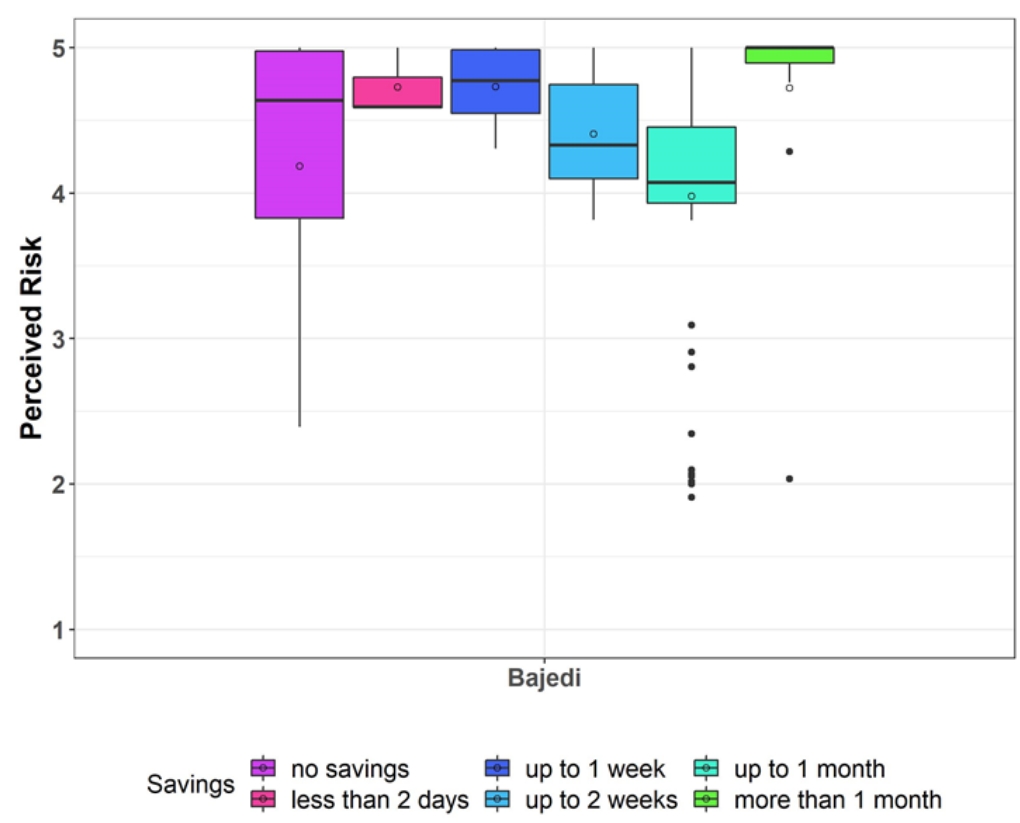

Figure 7. Boxplots of risk perception by the length of time for which households possess savings to survive after a landslide in Bajedi

As a form of debt, loans are likely to play a negative role in household respondents' risk and resilience perception (Gash and Gray 2016; Poshan et al. 2013). Figure 8 shows that outstanding or re-paid debt from having received a loan in the past 10 years for education, farm equipment, housing, marriage or repairs and maintenance is an influencing variable for risk perception in both villages. In Bajedi, the highest risk to landslides is perceived when households had taken out loans for repair and maintenance of their houses or for 'other purposes', which include medication. A wider data spread is observed for households haven 
taken out no loan. A possible explanation is that these loans had been intended for repair and maintenance in the aftermath of a landslide event. Consequently, based on their experience, those households would feel more at risk from landslides. It should however be noted that higher risk perception of those households having previously experienced landslides could simply be linked to being located in higher risk zones, depending on whether previous landslides were experienced elsewhere. In Sunkuda, households that had taken out loans for 'other purposes', including medication, felt most at risk from landslides. Loans for farm equipment or seeds are small, which can be explained by the very low returns for farming in these mountain villages.

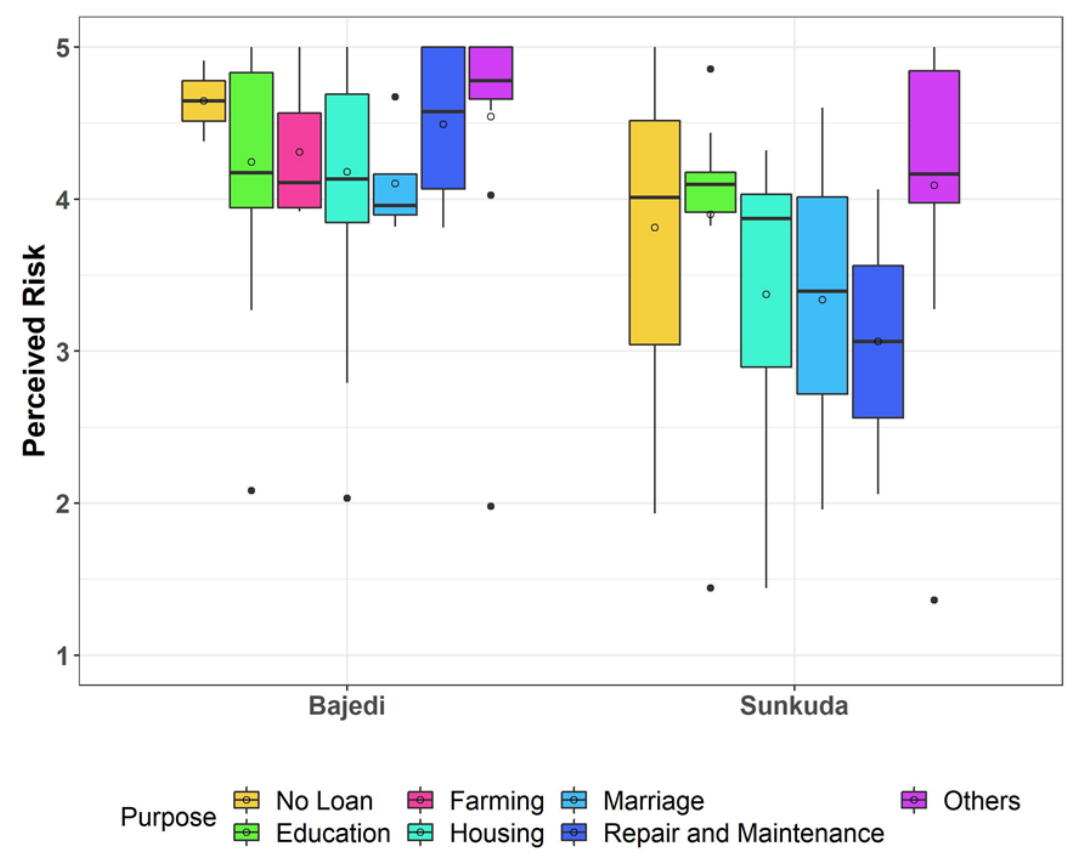

Figure 8. Boxplots of risk perception by the purpose of a loan taken out in the last 10 years in Bajedi (left) and Sunkuda (right)

The difficult economic situation in Sunkuda and Bajedi has led to increasing out migration, not only from Bajedi and Sunkuda, but throughout Nepal, causing a gradual shift from an agriculture-based to a remittance-based economy (Gartaula et al. 2012). Indeed, remittances are more than three times the size of official development assistance (World Bank 2016) and can be a significant contribution to post-disaster recovery. Remittances contributed to over a quarter of Nepal's national GDP in 2018/19 (Ministry of Finance 2019). The economic transition is also observed in this study area, where most households reportedly rely on remittances (30\%) and non-farming activities (28\%) as their main sources of income. 


\subsubsection{Natural and physical capital}

In addition to arable land, essential resources for household survival in Bajedi and Sunkuda include forests for raw materials such as wood fuel, water for drinking and washing, and solar power for electricity. In this exceedingly poor rural area, physical capital is thus closely interlinked with natural capital. Homes are built from local natural materials, mainly adobe, and there are few additional physical assets. It is not surprising then that natural capital plays an important role in how household respondents perceive the risk of landslides.

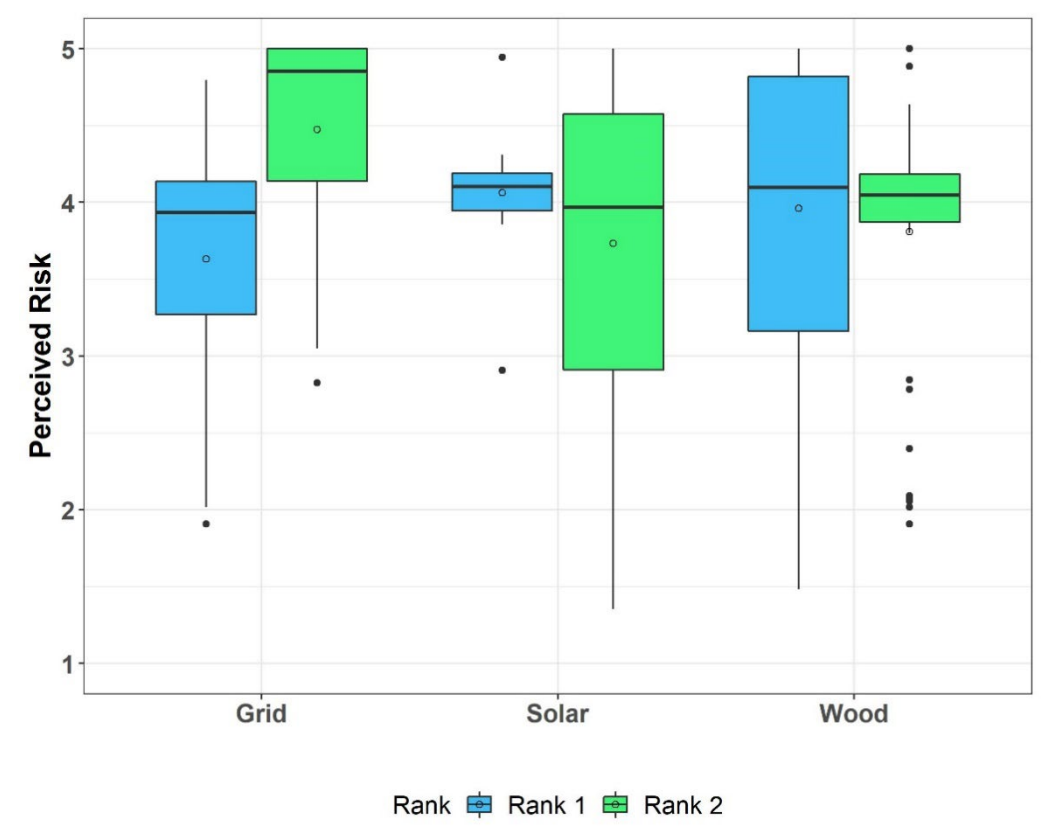

Figure 9. Boxplots of risk perception by main energy sources of households in Bajedi

In Bajedi, a main energy source for cooking and heating is wood (63\%) with solar and the grid playing a moderate role for electricity generation (34\%). Figure 9 shows how Bajedi household energy sources influence risk perception. Those households primarily relying on fuelwood have the highest risk perception. On the one hand, fuelwood is mainly harvested from community forests, meaning that accessibility and availability can decrease in the event of a landslide. Additionally, collecting wood often requires household members to travel long distances, further exposing them to landslides and consequently increasing their perceived risk. On the other hand, community forests are known to stabilize steep slopes, thereby decreasing landslide risk (Forbes et al. 2012; Promper et al. 2014; Sudmeier-Rieux et al. 2012). Results may then also signal the knowledge of forests' protective role from landslides. Figure 10 shows the influence of having access to a community forest on risk perception. 


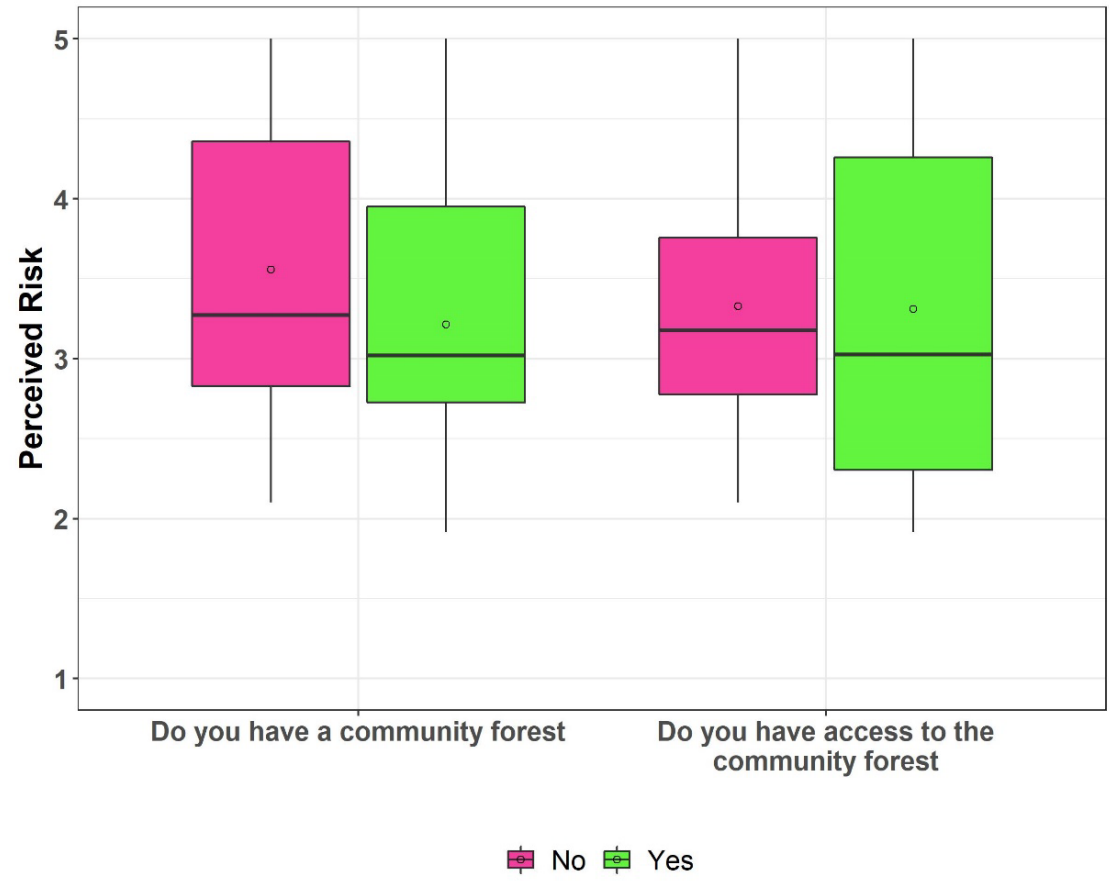

Figure 10. Boxplots of risk perception by the existence of a community forest (left) and access to this community forest (right) in Sunkuda

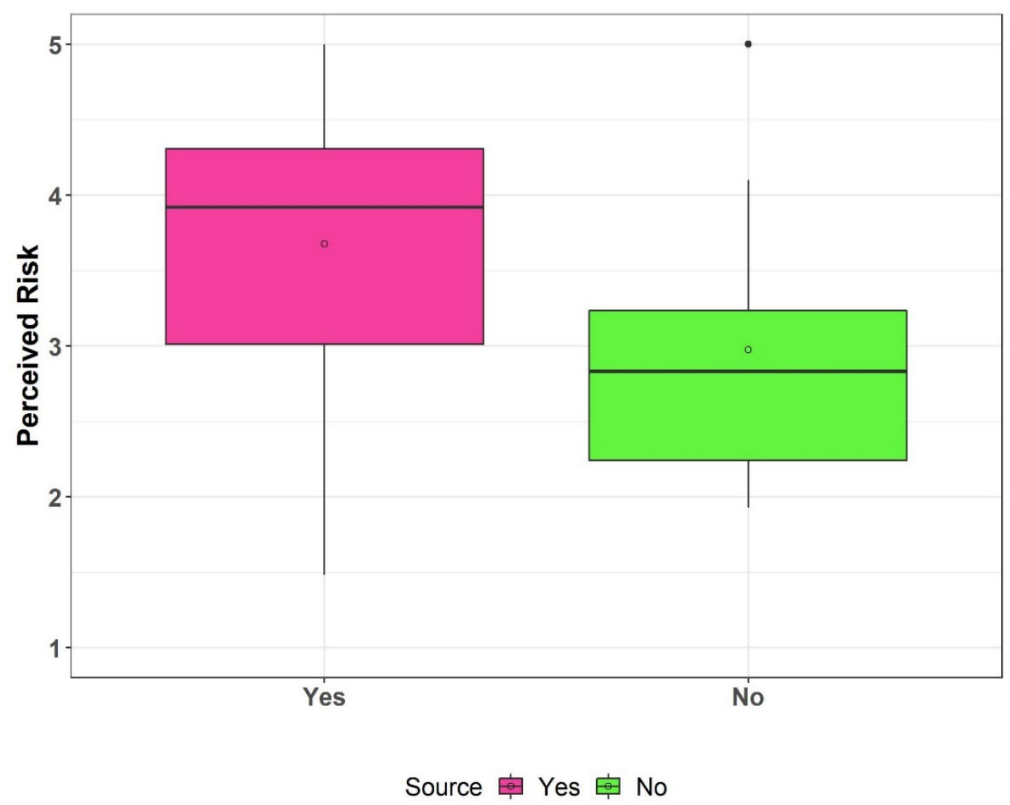

Figure 11. Boxplots of risk perception by whether households' main water source changed seasonally (left) or not (right) in Sunkuda

Another critical resource in the event of a landslide is potable water. The seasonal change of water availability is shown to be a key influence of risk perception in Sunkuda (figure 11), 
where respondents from households whose drinking water sources change seasonally feel more at risk from landslides than those whose water source remains constant over the year. The link between water availability and risk perception was also noted in rural Chongqing (China), where household surveys revealed that insufficient water quantity is associated with higher disaster risk perception (Ho et al. 2019). Moreover, it appears consistent that diversified water sources would impact on how much a household respondent feels at risk from landslides. While diversification can provide security in case one source is impacted, at the same time those households relying on diverse water sources are likely to travel further when their nearest water collection point is unusable, increasing individual exposure to a landslide during these journeys. Additionally, Cieslik et al. (2019) note that daily activities such as fetching water often represent opportunities to observe and monitor surroundings for signs of upcoming landslides. Thus, risk perception of those households having to travel further to fetch water could also be higher because they are more likely to notice possible early signs of change, e.g., cracked soil or increasing stream turbidity. A further result in both villages is the influence of which household member collects water on risk perception (figure 12).

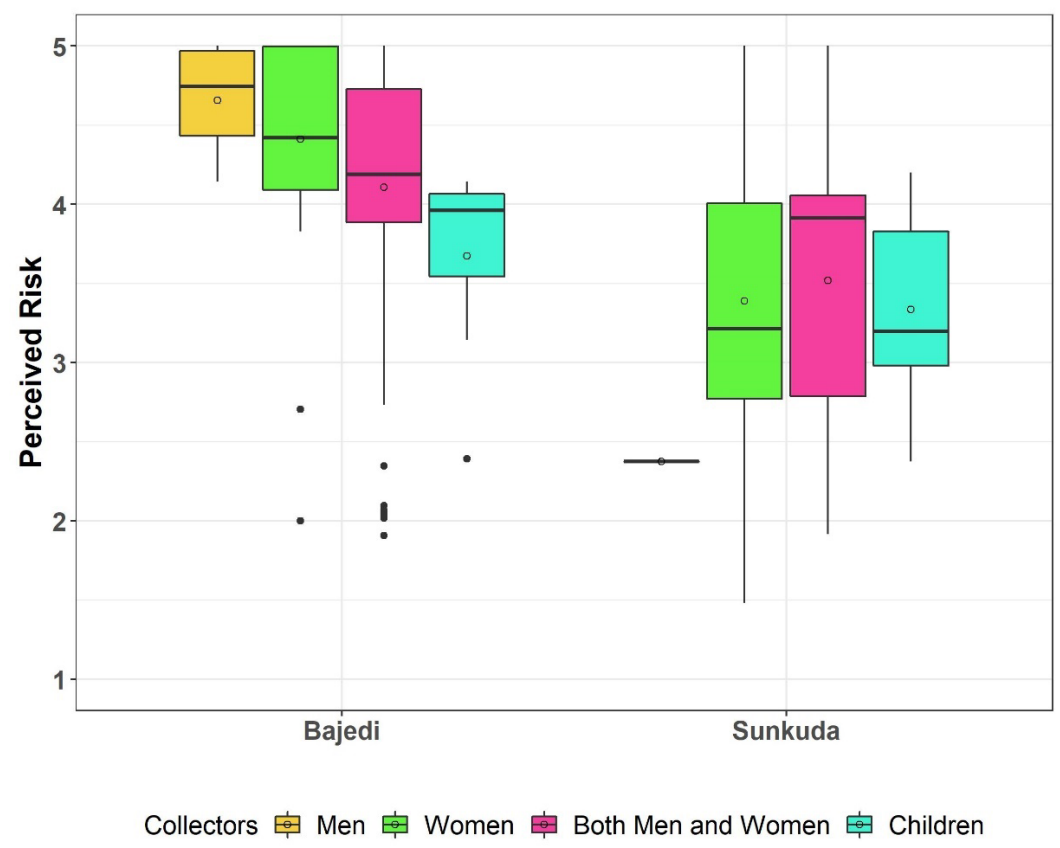

Figure 12. Boxplots of risk perception by the households' main water collector in Bajedi (left) and Sunkuda (right)

Findings show that once again, the general risk perception of respondents was considerably higher in Bajedi than in Sunkuda. In both villages, results show that risk perception of landslides is lowest when children collect drinking water for the household. This may mean that the main water source is nearby since children would only be able to carry water over short distances. In Bajedi, risk perception was highest when male members were the main water collectors. As male household members often migrate to nearby countries (mostly India) to 
seek employment, households in which males collect water are likely to be those for whom outmigration is not an option, for example due to health reasons, or those in which men managed to secure a local employment or income. This data trend could therefore be explained by increased vulnerability (e.g., illness or disability in a household) or dependence on the household's main earner. Data trends were less clear in Sunkuda, and when both men and women collected water.

\subsubsection{Socio-political capital}

\subsubsection{Social networks}

This section draws heavily on semi-structured interview data, which shows that Bajedi and Sunkuda households have developed complex social coping strategies to counteract what many views as inadequate support from municipal governments. This is most prominently demonstrated in the heavy reliance on social networks for materials, labour, finance, and knowledge transfer related to landside prevention and recovery. The study sites are characterized by a culture of mutual aid in the face of adversity. According to the interviews, households call on their social networks if they are struggling to cope after a landslide, for example by asking for shelter or food. As noted by a villager in Sunkuda:

In the event of disaster, neighbours are the ones who help. (Interviewee S114, 07/03/2020)

Whilst emergency aid such as food and shelter are given freely, other types of support like help with rebuilding or relocation is considered reciprocal, that is, interviewees reported expectations that this labour is returned in the future. This has resulted in an informal exchange economy with many affected households indebted to others; not only in the form of monetary loans, but in anticipated future labour (Thieme 2003). As noted earlier, the existence of monetary debts has an impact on risk perception with in-debt households reporting an increased sense of risk (see figure 8). The networks in the study sites are highly dense and based primarily on kinship and proximity, which are often interchangeable. In Sunkuda, for example, the village is comprised of communities of identifiable clusters of houses that are typically inhabited by extended family members. Network density can have an impact on resilience as dense networks have been shown to have low levels of adaptability and transformative potential (Mark S. Granovetter 1973). Networks that have a higher number of non-connected actors have greater access to different types of knowledge and more information sources. Another weakness of dense networks is that close neighbours are likely equally affected by the hazard, rendering the support network less effective. As expressed by a member from a community located in close proximity to the Dhokla landslide in Sunkuda:

If my house is in danger, even neighbours will be affected - so at that time everyone here will be affected by the hazard. (Interviewee S135, 09/03/2020) 
Knowledge transfer, social learning and social influence (such as discussing a hazard within social networks) are common mechanisms that shape risk perception (Helleringer and Kohler 2005). While non-connected networks may have access to more information sources, In Bajedi and Sunkuda, kinship networks are important for knowledge transfer in that they substitute for the poor communication from government officials. As one interviewee stated:

Information sharing [regarding landslides] especially takes place among family members, close relatives and neighbours and it's been helpful. Nothing has been done from the government side. (Interviewee S134, 09/03/2020)

Alongside local knowledge transfer, kinship networks can also impact risk and resilience perceptions via their relationship with outmigration. As discussed earlier, surveyed households rely heavily on remittances as an income source that is unaffected in the case of a disaster. This further highlights the importance of social networks and kinship for risk mitigation strategies.

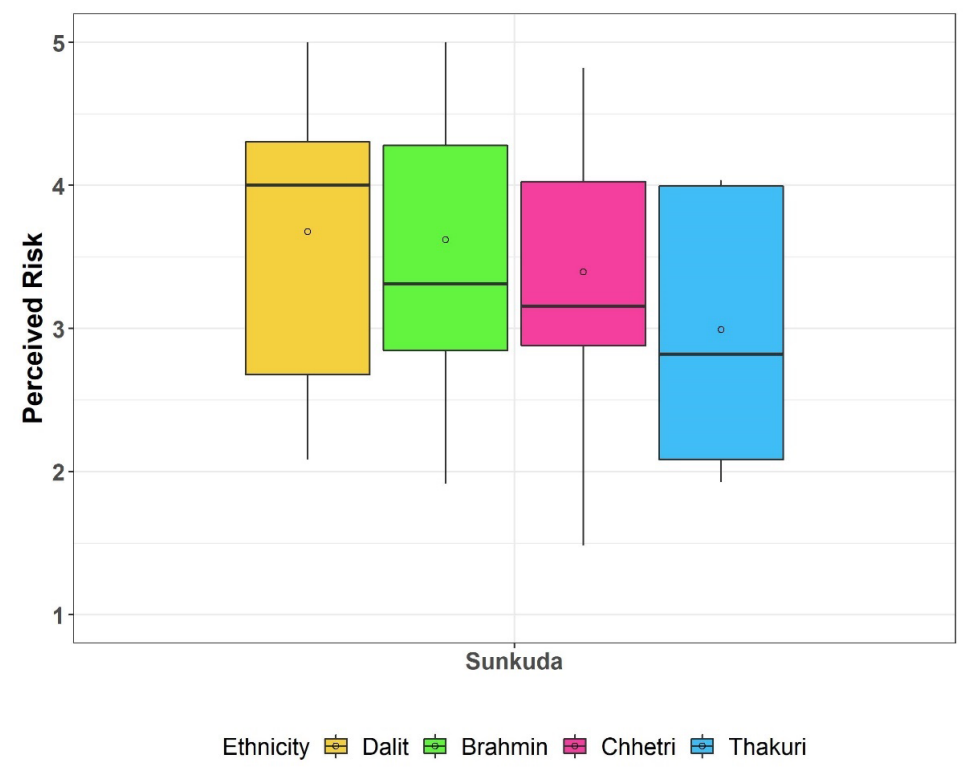

Figure 13. Boxplots of risk perception by households' ethnicities in Sunkuda

Closely related to social networks, the survey showed ethnicities to be a significant influencing factor on risk perception in Sunkuda. Figure 13 shows that high caste ethnicities, such as Brahmin, perceive landslide risk as higher compared to the low caste Dalit ethnicity. The main reasons behind this may be that high caste households are located closer to the landslide zone in Sunkuda, and they have greater financial assets (in this context meaning land and livestock), thus 'more to lose'. In this case, it is not 'ethnicity' that is the explanatory factor, but risk exposure.

Additionally, higher caste ethnicities often benefit from higher education levels, which are important for building risk awareness. The role education plays in increasing risk awareness 
and preparedness is well documented (Bernhardsdottir et al. 2016; Cerulli et al. 2020; Education 2011; Muttarak and Lutz 2014). In 2005-2015, Nepal adopted a DRR framework (the Hyogo Framework for Action), which emphasized the role of education, especially, school disaster education for forming culture of disaster prevention (Ministry of Home Affairs Nepal; Dangal 2015). Nevertheless, research confirmed that initiatives taken for disaster education in Nepal are not yet sufficient (Shiwaku et al. 2007; Tuladhar et al. 2014).

\subsubsection{Governance}

In Nepal, disaster governance - legislation, institutions, and procedures - are evolving. At the national level, paradigms of governance have changed from an emphasis on response and recovery to more attention to disaster risk reduction (DRR). However, at the local level the responsible municipal institutions have focused primarily on disaster response and recovery, especially in Far West Nepal and including the field study sites (Vij et al., 2020). The dominance of a 'response and recovery' paradigm is partly due to the limited presence of NGOs and INGOs in the far-western region (ibid). Moreover, due to the recent federalization processes in Nepal, the local governments have not had sufficient time to design and implement disaster governance plans and strategies. Interview respondents mentioned that barriers to better disaster risk management include a lack of clarity among local governance functionaries, political and bureaucratic struggles, and corruption. In the words of two interviewees:

Nothing has been done for development or disaster risk reduction. It's mainly because of political reasons. Leaders are more concerned about individual benefits than community development work. It's a trend everywhere, those who are educated and influential are focused on individual profit. (Interviewee S154, 06/03/2020)

Nothing has been provided from the municipality. But even if they provide [support], they give it to their own party's people. (Interviewee S026, 09/03/2020)

The interviews also reveal mistrust in government authorities, which has resulted in low expectations in case of a landslide. While local governments have access to emergency funds, there are no standard operating procedures on how to mobilize these funds. Furthermore, despite the existence of a disaster management committee - a committee formed under the chairmanship of the municipal mayor and ward heads after the introduction of the Nepal Disaster Risk and Management Act 2017 (Nepal, Khanal, and Pangali Sharma 2018) - few of its members are trained in DRR-related issues.

They form [disaster management] committees, and they elect chairs and members. Today they form a [disaster management] committee here, and tomorrow in another village, but after that they do nothing. (Interviewee S148, 12/03/2020)

Consequently, there is a lack of clarity on roles and responsibilities during disaster situations. The lack of communication and support from the government was reinforced by the interviews. As one interviewee put it: 
...no one has told us once that we are at risk or that they [the government] will help us. We have not heard a single word from any person [authority or leader] here. (Interviewee S026, 09/03/2020)

Workshop discussions revealed concern about the disaster response from the local government, which was viewed by many participants as too slow, and risk reduction measures as extremely limited. Another identified governance gap was the failure of the government to include local, traditional knowledge in its management practices. For instance, locally observed early warning signs for landslides, such as changes in land subsidence, drying up of water sources or changes in the orientation of rocks, are reportedly not included in landslide monitoring. Such knowledge could be particularly useful for citizen science approaches attempting to fill information gaps in this data-scarce region (Parajuli et al. 2020).

Apart from these insights elicited from workshops and interviews, governance factors elicited in the survey were noticeably absent as drivers of risk perception. This reinforces the previously highlighted sense of dissociation between risk experienced at the local household level and the policy decisions taken at the institutional level.

\subsubsection{Human capital}

The survey and interview results show that the most prevalent risk perception drivers, as discussed above, relate to financial, natural-physical, and socio-political capitals. Indicators of human capital as derived from survey questions on disaster preparedness (Appendix 1, Part 6) and household education (Appendix 1, Part 5) played a negligent role in explaining risk perception in the two villages. The results are thus interesting in what they do not show, namely that factors relating to human capital are significant drivers of risk perception compared to the other four capitals, despite the recognition of education's critical role in influencing disaster vulnerability (Muttarak and Lutz 2014).

One exception is the significance of the lack of knowledge of an emergency number in case of a landslide (figure 14).

As shown in figure 14, most surveyed households do not know whom to call in the case of a landslide, although less so in Sunkuda. This lack of information has significant, although mixed, results on risk perception. The results signal, moreover, a lack of disaster preparedness communication on the part of the authorities. In the words of an interviewee:

We know about [landslides] from the media. They inform about the weather forecast and tell us to be prepared [for landslides]. But at the local level, there are no practices of sharing information (...) nor has any initiative been taken about it. (Interviewee S144, $12 / 03 / 2020)$

Relating to this, the analysis also reveals a more deeply rooted problem than lack of communication from leaders in case of a landslide: government authorities themselves often lack the information to provide early warning of landslides. As noted by an interviewee: 
If they [the government officials and leaders] have heard [about landslide risk], they give us this information, but if they are not informed themselves, how do they tell us? (Interviewee S154, 06/03/2020)

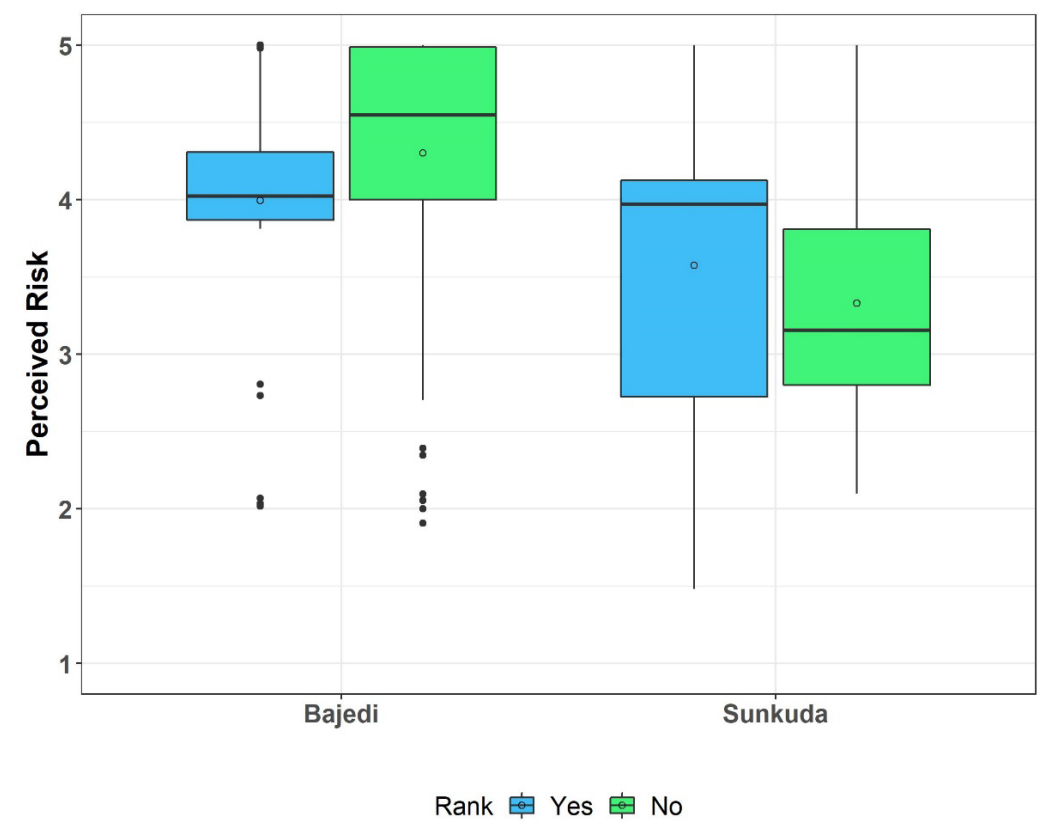

Figure 14. Boxplots of survey responses to the question "Do you know who to call in case of a landslide?" in Bajedi (left) and Sunkuda (right)

The results raise the science and policy issue of providing for a landslide early warning system (EWS). While EWS are gaining attention as important disaster risk mitigation strategies, their application to landslides remains limited due to the complexity of slope monitoring and underlying geomorphological processes (Calvello 2017; Kanta Kafle 2017). In Nepal, EWS for landslides have been shown to be hampered by a lack of policy and legal frameworks (including the absence of a national early warning centre, ineffective monitoring and evaluation, inadequate funding, and the lack of coordination among responsible bodies) resulting in fragmented capacity building efforts that have mainly emerged from individual development projects (Kanta Kafle 2017).

\section{CONCLUSIONS}

Based on structured surveys, interviews and stakeholder workshops, this study presents insights into landslide risk and resilience perceptions in two villages in rural Far West Nepal and distils key drivers of risk perception at household level. 
Results show that landslides are seen as a worsening existential threat in both villages. Findings also show that an overwhelming majority of respondents view their resilience in terms of their coping, adaptive and transformative capacities as low. Perceived risk was higher in Bajedi, which is more vulnerable to landslides owing to its remoteness, lack of infrastructure and recent experience of extreme landslides. Risk perception in this village is mainly driven by financial factors, such as the household's savings, income sources and loans. Factors related to natural and physical capitals, such a household's main energy source and main water collector, also played key roles in driving risk perception.

In Sunkuda, risk perception is influenced by previous risk experience (i.e., a previous landslide having damaged respondents' houses), as well as natural capitals including the seasonality and type of water sources and access to a community forest. Financial factors, such as expenditure on medication and loans, were also important risk perception drivers. The risk perception of respondents in both villages was shaped by whom collected water in the household, existing loans, and debts, and by whether household members knew whom to call in case of a landslide.

The analysis highlights the complexity of perceived landslide risk and resilience, which are inextricably linked in our results. Indeed, risk perception was mainly driven by what is often defined as resilience indicators (i.e., the five capitals). The study findings show that risk perception was primarily driven by financial capital, closely followed by natural and physical capital, which were often overlapping due to the villages' direct dependence on natural resources such as water and firewood. This was particularly true in Bajedi, where remoteness and lacking infrastructure has increased vulnerability. Factors relating to socio-political capital were also crucial, yet harder to quantify in the survey results. Indeed, interviews revealed that kinship and social networks are fundamental for coping with disasters, as help and support is primarily provided by neighbours. In terms of political capital, it is mainly the absence of efficient risk governance structures that played a role in influencing risk perception. Disaster response and mitigation expectations from local authorities and leaders were low to nonexistent. Interviews also highlighted the mistrust in a government which has, according to interviewees, so far neglected villagers when landslides occurred. Human capital was little represented in the results, and mainly influenced risk perception in terms of emergency number knowledge. The paper thus emphasises the multi-dimensional nature of risk and resilience perception and signals the need for systemic approaches and solutions to increase disaster risk reduction and mitigation strategies in this region.

The UN Sendai Framework (UNISDR 2015) calls for investment in risk mitigation and preparedness, rather than solely focusing on emergency response. Yet, our findings show that although progress has been made in disaster risk governance in Nepal, disaster paradigms still largely focus on disaster response rather than preparedness. Interviews and stakeholder workshop results clearly reveal a mismatch between communities' risk perception at the household level and DRR decision-making at the municipal and national level. This is further emphasized by traditional knowledge on landslides' early warning signs currently being 
unaccounted for in risk mitigation strategies. Thus, the use of indigenous and traditional knowledge on landslides represents an important potential data source for enhancing landslide risk management. The overwhelming majority of surveyed households felt unprepared for landslides and were not engaged in (or even informed about) any possible mitigation measures, highlighting a gap in the sites' current risk governance. Our findings are thus of importance to guide authorities in designing future bottom-up risk reduction and mitigation measures, which are currently limited in the studied sites.

\section{ACKNOWLEDGEMENTS}

The authors would like to thank the UK's Natural Environment Research Council (NERC) and Department for International Development (DFID) for the financial support kindly provided through the "Citizen Science for Landslide Risk Reduction and Disaster Resilience Building in Mountain Regions - (Landslide-EVO) project" as a part of the Science for Humanitarian Emergencies and Resilience (SHEAR) program (grant number NE/P000452/1). We acknowledge the valuable participation from the local stakeholders including the members of 193 households surveyed of the Bajedi and Sunkuda communities of Bajura and Bajhang district, respectively. In particular, we would like to thank Pushpa Chad, Sangita Pal, Bhoj Raj Bhatta, and Chet Raj Pant from the Far Western University of Nepal for their help in conduction households survey in Landslide-EVO study areas.

\section{REFERENCES}

Aboagye, D., Dari, T., and Koomson, J. (2013) Risk Perception and Disaster Management in the Savannah Region of Ghana, International Journal of Humanities and Social Science, 3 (3): 85-96. https://www.researchgate.net/publication/308148571_Risk_perception_and _disaster_management_in_the_Savannah_Region_of_Ghana

Ahmad, D., and Afzal, M. (2020) Flood Hazards and Factors Influencing Household Flood Perception and Mitigation Strategies in Pakistan, Environmental Science and Pollution Research, 27 (13): 15375-15387. https://doi.org/10.1007/s11356-020-08057-z

Antronico, L., De Pascale, F., Coscarelli, R., and Gullà, G. (2020) Landslide Risk Perception, Social Vulnerability and Community Resilience: The Case Study of Maierato (Calabria, Southern Italy) International Journal of Disaster Risk Reduction, 46, Article 101531. https://doi.org/10.1016/j.ijdrr.2020.101529

Barnett, B. J., Barrett, C. B., and Skees, J. R. (2008) Poverty Traps and Index-Based Risk Transfer Products, World Development, 36 (10): 1766-1785. https://doi.org/10.1016/ j.worlddev.2007.10.016

Béné, Christophe, Wood, R. G., Newsham, A., and Davies, M. (2012) Resilience: New Utopia or New Tyranny? Reflection about the Potentials and Limits of the Concept of Resilience in Relation to Vulnerability Reduction Programmes, IDS Working Papers, Vol. 2012, (405), 1-61. https://doi.org/10.1111/j.2040-0209.2012.00405.x 
Berman, R. J., Quinn, C. H., and Paavola, J. (2015) Identifying Drivers of Household Coping Strategies to Multiple Climatic Hazards in Western Uganda: Implications for Adapting to Future Climate Change, Climate and Development 7 (1): 71-84. https://doi.org/10.1080/17565529.2014.902355

Bernhardsdottir, A. E., Musacchio, G., Ferreira, M. A., and Falsaperla, S. (2016) Informal education for disaster risk reduction, Bulletin of Earthquake Engineering, 14 (7): 21052116. https://doi.org/10.1007/s10518-015-9771-9

Bustillos Ardaya, A., Evers, M., and Ribbe, L. (2017) What Influences Disaster Risk Perception? Intervention Measures, Flood and Landslide Risk Perception of the Population Living in Flood Risk Areas in Rio de Janeiro State, Brazil, International Journal of Disaster Risk Reduction, 25(September): 227-237. https://doi.org/10.1016/j.ijdrr.2017. 09.006

Butler, D., R., and DeChano, L. M. (2012) Landslide Risk Perception, Knowledge and Associated Risk Management: Case Studies and General Lessons from Glacier National Park, Montana, USA, Landslide Hazard and Risk: 199-218. https://doi.org/ 10.1002/9780470012659.ch6

Cai, H., Lam, N. S. N., Qiang Y., Zou, L., Correll, R. M., and Mihunov, V. (2018) A Synthesis of Disaster Resilience Measurement Methods and Indices, International Journal of Disaster Risk Reduction, 31: 844-855. https://doi.org/10.1016/j.ijdrr.2018.07.015

Calvello, M. (2017) Early Warning Strategies to Cope with Landslide Risk, Rivista Italiana Di Geotecnica, 2/17(2), 63-91. https://doi.org/10.19199/2017.2.0557-1405.063

Calvello, M., Papa, M. N., Pratschke, J., and Crescenzo, M. N. (2016) Landslide Risk Perception: A Case Study in Southern Italy, Landslides 13 (2): 349-360. https://doi .org/10.1007/s10346-015-0572-7

Cerulli, D., Scott, M., Aunap, R., Kull, A, Pärn, J., Holbrook, J., and Mander, Ü. (2020) The Role of Education in Increasing Awareness and Reducing Impact of Natural Hazards. Sustainability (Switzerland) 12 (18): 1-14. https://doi.org/10.3390/su12187623

Cieslik, Katarzyna, Shakya, P., Uprety, M., Dewulf, A., Russell, C., Clark, J., Dhital, M. R., and Amrit Dhakal. (2019) Building Resilience to Chronic Landslide Hazard Through Citizen Science, Frontiers in Earth Science, 7(November): 1-19. https://doi.org/10.3389/ feart.2019.00278

Damm, A., Eberhard, K., Sendzimir, J., and Patt, A. (2013) Perception of Landslides Risk and Responsibility: A Case Study in Eastern Styria, Austria, Natural Hazards 69 (1): 165-183. https://doi.org/10.1007/s11069-013-0694-y

Department for International Development (DFID). (2013) Regional Dimensions of Poverty and Vulnerability in Nepal - Background Reports. 1-263. https://assets.publishing.servic e.gov.uk/government/uploads/system/uploads/attachment_data/file/209483/Regional-dim ension-poverty-nepal-background.pdf

Department for International Development (DFID). (1999) Sustainable Livelihoods Guidance Sheets, Section 2.1., 1-150. https:/www.livelihoodscentre.org/documents/114097690/ 114438878/Sustainable+livelihoods+guidance+sheets.pdf/594e5ea6-99a9-2a4e-f288cbb4ae4bea8b?t=1569512091877

Douglas, M. (1979) World View and the Core, Philosophical Disputes in the Social Sciences. S. C. Brow (e.d). Sussex, Harvester Press. 
Elith, J., Leathwick, J. R., and Hastie, T. (2008) A Working Guide to Boosted Regression Trees, Journal of Animal Ecology, 77 (4): 802-813. https://doi.org/10.1111/j.13652656.2008.01390.x

Forbes, K., Broadhead, J., Bischetti, G. B., Brardinoni, F., Dykes, A., Gray, D., Lmaizumi, F., Kuriakose, S. L., Osman, N., Petley, D., Stokes, A., Verbist B., and Wu, T. H. (2012) Forests and Landslides: The Role of Trees and Forests in the Prevention of Landslides and Rehabilitation of Landslide-Affected Areas in Asia. Second Edition, Food and Agriculture Organization of the United Nations, Regional office for Asia and the Pacific (RAP) publication, 12-21. https://www.fao.org/3/i3245e/i3245e.pdf

Froude, M. J., and Petley, D. N. (2018) Global Fatal Landslide Occurrence 2004 to 2016, Natural Hazards and Earth System Sciences Discussions, 18 (8) (2012):1-44. https://doi.org/10.5194/nhess-18-2161-2018

Gartaula, H., Niehof, A., and Visser, L. (2012) Shifting Perceptions of Food Security and Land in the Context of Labour Out-Migration in Rural Nepal, Food Security 4 (2): 181-94. https://doi.org/10.1007/s12571-012-0190-3

Gash, M., and Gray, B. (2016) The Role of Financial Services in Building Household Resilience in Burkina Faso, CGAP Clients at the Center. https://pdf.usaid.gov/pdf_docs/PA00XTCZ.pdf

Gelman, A., and Hill, J. (2006) Data Analysis Using Regression and Multilevel/Hierarchical Models, Cambridge: Cambridge University Press.

Granovetter, M. S. (1973) The Strength of Weak Ties, American Journal of Sociology 78 (6): 1360-1380. http://www.jstor.org/stable/2776392

Harris, J. A., Denyer, D., Harwood, S., Braithwaite, G., Jude, S., \& Jeffrey, P.(2020) Time to $\begin{array}{lllll}\text { invest in global } & \text { resilience, Nature } 583 \quad \text { (7814): } 30 .\end{array}$ https://www.nature.com/articles/d41586-020-01951-z

He, Z., and Zhai, G. (2015) Spatial Effect on Public Risk Perception of Natural Disaster: A Comparative Study in East Asia, Journal of Risk Analysis and Crisis Response 5 (3): 161. https://doi.org/10.2991/jrarc.2015.5.3.3

Helleringer, S., and Kohler, H. P. (2005) Social Networks, Perceptions of Risk, and Changing Attitudes towards HIV/AIDS: New Evidence from a Longitudinal Study Using FixedEffects Analysis, Population Studies 59 (3): 265-282. https://doi.org/10.1080/0032 4720500212230

Hernández-Moreno, G., and Alcántara-Ayala, I. (2017) Landslide Risk Perception in Mexico: A Research Gate into Public Awareness and Knowledge, Landslides, 14 (1): 351-371. https://doi.org/10.1007/s10346-016-0683-9

Ho, J. Y. E., Chan, E. Y. Y., Lam H. C. Y., Yeung, M. P. S., Wong, C. K. P., and Yung, T. K. C. (2019) Is "Perceived Water Insecurity" Associated with Disaster Risk Perception, Preparedness Attitudes, and Coping Ability in Rural China? (A Health-EDRM Pilot Study), International Journal of Environmental Research and Public Health 16 (7). https://doi.org/10.3390/ijerph16071254

Ho, Ming-chou, Shaw, D., Lin, S., and Chiu, Y. (2008) How Do Disaster Characteristics Influence Risk Perception?, Risk Analysis, 28 (3): 635-643. https://doi.org/10.1111/j.15396924.2008.01040.x 
IPCC. (2020) The Concept of Risk in the IPCC Sixth Assessment Report: A Summary of Cross-Working Group Discussions. https://www.ipcc.ch/site/assets/uploads/2021/ 02/Risk-guidance-FINAL_15Feb2021.pdf

Jones, L. (2018) New Methods in Resilience Measurement Early Insights From a Mobile Phone Survey in Myanmar using subjective Tools, BRACED, 1-65. Retrieved October 27, 2021. http://www.braced.org/contentAsset/raw-data/20a0886a-4975-45a5-8a83-339618dc9bf8/ attachmentFile

Jones, L., and Tanner, T. (2017) 'Subjective Resilience': Using Perceptions to Quantify Household Resilience to Climate Extremes and Disasters, Regional Environmental Change, 17 (1): 229-243. https://doi.org/10.1007/s10113-016-0995-2

Kafle, K. S. (2017) Disaster Early Warning Systems in Nepal: Institutional and Operational Frameworks, Journal of Geography \& Natural Disasters, 7 (2). https://doi.org/10.4172/2167-0587.1000196

Keating, A., Campbell, K., Mechler, R., Magnuszewski, P., Mochizuki, J., Liu, W., Szoenyi, M., and McQuistan, C. (2017) Disaster Resilience: What It Is and How It Can Engender a Meaningful Change in Development Policy, Development Policy Review, 35 (1): 65-91. https://doi.org/10.1111/dpr.12201

Linnerooth-Bayer, J., Surminski, S., Bouwer, L. M., Noy, I., \& Mechler, R. (2019) Insurance as a Response to Loss and Damage?, In: Loss and Damage from Climate Change , Springer, Cham., 483-512. https://link.springer.com/chapter/10.1007/978-3-319-720265_21

Liu, D., Li, Y, Shen, X, Xie, Y., and Zhang Y. (2018) Flood Risk Perception of Rural Households in Wester Mountainous Regions of Henan Province, China, International Journal of Disaster Risk Reduction, 27: 155-60. https://doi.org/10.1016/j.ijdrr.2017.09. 051

McAdoo, B. G., Quak, M., Gnyawali, K., Adhikari, B., Devkota, S., Rajbhandari, P., and Sudmeier, K. (2018) Brief Communication: Roads and Landslides in Nepal: How Development Affects Risk, Natural Hazards and Earth System Sciences Discussions, (1979): 1-6. https://doi.org/10.5194/nhess-2017-461

Ministry of Finance Nepal. (2019) "Economic Survey 2018/19." Government of Nepal, Ministry of Finance, 1-340. https://www.mof.gov.np/uploads/document/file/compiled\%2 0economic\%20Survey\%20english\%207-25_20191111101758.pdf

Ministry of Home Affairs Nepal; Dangal, R. (2015) Nepal National Progress Report on the Implementation of the Hyogo Framework for Action (2013-2015), Government of Nepal, Ministry of Home Affairs. https://www.preventionweb.net/files/41755_NPL_NationalHF Aprogress_2013-15.pdf

Muñoz-Torrero Manchado, A., Allen, S., Ballesteros-Cánovas, J. A., Dhakal, A., Dhital, M. R. and Stoffel, M. (2021) Three decades of landslide activity in western Nepal: new insights into trends and climate drivers, Landslides 18, 2001-2015 (2021). https://doi.org/ 10.1007/s10346-021-01632-6

Muttarak, R., and Lutz, W. (2014) Is Education a Key to Reducing Vulnerability to Natural Disasters and Hence Unavoidable Climate Change?, Ecology and Society, 19 (1). http://dx.doi.org/10.5751/ES-06476-190142 
Nathan, F. (2008) Risk Perception, Risk Management and Vulnerability to Landslides in the Hill Slopes in the City of La Paz, Bolivia. A Preliminary Statement, Disasters, 32 (3): 337-57. https://doi.org/10.1111/j.1467-7717.2008.01043.x

Nepal, P., Khanal, N. R., and Sharma, B. P. P. (2018) Policies and Institutions for Disaster Risk Management in Nepal: A Review, Geographical Journal of Nepal, 11: 1-24. https://doi.org/10.3126/gjn.v11i0.19546

Parajuli, B. P., Khadka, P., Baskota, P., Shakya, P., Liu, W., Pudasaini, U., Roniksh, B. C., Paul, J. D., Buytaert, W., and Vij, S. (2020) An Open Data and Citizen Science Approach to Building Resilience to Natural Hazards in a Data-Scarce Remote Mountainous Part of Nepal, Sustainability (Switzerland) 12 (22):1-13. https://doi.org/10.3390/su12229448

Peacock, W. G., Brody, S. D., and Highfield, W. (2005) Hurricane Risk Perceptions among Florida's Single Family Homeowners, Landscape and Urban Planning, 73 (2-3): 120-135. https://doi.org/10.1016/j.landurbplan.2004.11.004

Petley, D. N., Hearn, G. J., Hart, A., Rosser, N. J., Dunning, S. A., Oven, K, and Mitchell, W. A. (2007) Trends in Landslide Occurrence in Nepal, Natural Hazards 43 (1): 23-44. https://link.springer.com/article/10.1007/s11069-006-9100-3

Promper, C., Puissant, A., Malet, J. P., and Glade, T. (2014) Analysis of Land Cover Changes in the Past and the Future as Contribution to Landslide Risk Scenarios, Applied Geography 53: 11-19. https://doi.org/10.1016/j.apgeog.2014.05.020

RSS. (2020) Four Settlements Displaced in Bajura, My Republica. Retrieved February 13, 2021. https://myrepublica.nagariknetwork.com/news/four-settlements-displaced-inbajura/

Schipper, Lisa F., and Langston, L. (2015) A Comparative Overview of Resilience Measurement Frameworks Analysing Indicators and Approaches, ODI, 422.. http://dx.doi.org/10.13140/RG.2.1.2430.0882

Serfilippi, E., and Ramnath G. (2018) Resilience Measurement and Conceptual Frameworks: A Review of the Literature, Annals of Public and Cooperative Economics, 89 (4): 645-64. https://doi.org/10.1111/apce.12202

Sharifi, A., and Yamagata, Y. (2016) On the Suitability of Assessment Tools for Guiding Communities towards Disaster Resilience, International Journal of Disaster Risk Reduction, 18: 115-124. https://doi.org/10.1016/j.ijdrr.2016.06.006

Shiwaku, K., Shaw, R., Kandel, R. C., Shrestha, S. N., and Dixit, A. M. (2007) Future Perspective of School Disaster Education in Nepal, Disaster Prevention and Management, 16 (4): 576-587. https://doi.org/10.1108/09653560710817057

Singh, P. (2018) Bajura Locals Fear Budiganga River Blockage - The Himalayan Times Nepal's No.1 English Daily Newspaper | Nepal News, Latest Politics, Business, World, Sports, Entertainment, Travel, Life Style News. The Himalayan Times. Retrieved February 13, 2021 (https://thehimalayantimes.com/nepal/bajura-locals-fear-budiganga-riverblockage/).

Sjöberg, L., Moen, B. E., \& Rundmo, T. (2004) Explaining risk perception, An evaluation of the psychometric paradigm in risk perception research, Rotunde, 84: 1-30. https://www.re searchgate.net/profile/Ingo-Riess/post/Can_anyone_recommend_a_suitable_and_validat ed_tool_to_measure_a_persons_risk_perception_and_safety_values/attachment $/ \overline{59} \mathrm{~d} 6392$ d79 $197 \overline{\mathrm{b}} 807799663 \overline{\mathrm{f}} / \mathrm{AS} \% 3 \mathrm{~A} 400743224889344 \% 40 \overline{1} 472556038267 /$ download/2004_ris k-perception.pdf 
Shaw, D. and Shiwaku, K. and Takeuchi, Y. (2011) Community, Environment and Disaster Risk Management, Disaster Education. Vol. 7 Emerald Group Publishing Limited, https://doi.org/10.1108/S2040-7262(2011)0000007017

Sharma, J. Marshak, A. and Stites, E., Poshan, D. (2013) Living in the Margins: Coping with Flood Risks and Managing Livelihoods in Nepal' s Far-Western Terai, Feinstein International Center Tufts University: 1-42. https://fic.tufts.edu/assets/TUFTS_1385 _Nepal_2_online-UPDATED.pdf

Slovic, P., Fischhoff, B., \& Lichtenstein, S. (1980) Facts and fears: Understanding perceived r isk. In: Societal risk assessment, Springer, 181-216. https://link.springer.com/chapter/10. 1007/978-1-4899-0445-4_9

Suarez, P. \& Linnerooth-Bayer, J. (2011) Insurance-related instruments for disaster risk reduc tion, 2011 Global Assessment Report on Disaster Risk Reduction, UNISDR. http://pure.ii asa.ac.at/id/eprint/9726/1/Suarez_\&_Linnerooth-Bayer_2011.pdf

Sudmeier-Rieux, K., Jaquet, S., Derron, M. H., Jaboyedoff, M., and Devkota, S. (2012) A Case Study of Coping Strategies and Landslides in Two Villages of Central-Eastern Nepal, Applied Geography 32 (2): 680-690. http://doi.org/10.1016/j.apgeog.2011.07.005

Sudmeier-Rieux, Karen, Mcadoo, B. G., Devkota, S., Rajbhandari, P. C. L., Howell, J. and Sharma, S. (2019) Invited perspectives: Mountain Roads in Nepal at a New Crossroads, Natural Hazards and Earth System Sciences, 19 (3): 655-660. https://nhess.copernicus.org/articles/19/655/2019/

Thieme, S. (2003) Savings and Credit Associations and Remittances: The Case of Far West Nepalese Labour Migrants in Delhi, India. Social Finance Programme International Labour Office, 39. http://www.ilo.org/public/libdoc/ilo/2003/103B09_237_engl.pdf

Tobin, G. A., Whiteford, L. M., Jones, E. C., Murphy, A. D., Garren, S. J., and Padros, C. V. (2011) The Role of Individual Well-Being in Risk Perception and Evacuation for Chronic vs. Acute Natural Hazards in Mexico, Applied Geography 31(2): 700-711. https://doi.org/10.1016/j.apgeog.2010.12.008

Tuladhar, G., Yatabe, R., Dahal, R. K., and Bhandary, N. P. (2014) Knowledge of Disaster Risk Reduction among School Students in Nepal, Geomatics, Natural Hazards and Risk, 5(3): 190-207. https://doi.org/10.1080/19475705.2013.809556

UNDP. (2015) Strengthening Disaster Risk Governance: UNDP Support during the HFA Implementation Period 2005-2015, UNDP, 1-102. https://www.undp.org/publications/strengthening-disaster-risk-governance

UNISDR. (2015) Sendai Framework for Disaster Risk Reduction 2015-2030, UNISDR. https://www.preventionweb.net/files/43291_sendaiframeworkfordrren.pdf

Vij, S., Russell, C., Clark, J., Parajuli, B. P., Shakya P., and Dewulf, A. (2020) Evolving Disaster Governance Paradigms in Nepal, International Journal of Disaster Risk Reduction, 50(May):101911. https://doi.org/10.1016/j.ijdrr.2020.101911

Vuillez, C., Tonini, M., Sudmeier-Rieux, K., Devkota, S., Derron, M. H. and Jaboyedoff, M. (2018) Land Use Changes, Landslides and Roads in the Phewa Watershed, Western Nepal from 1979 to 2016, Applied Geography, 94: 30-40. https://doi.org/10.1016/j.apgeo g.2018.03 M..003 
de Weijer, F., and McCandless, E. (2015) Capacity Development and Resilience, Capacity Development Beyond Aid, 81-92. https://ecdpm.org/wp-content/uploads/CAPACITY_B OOKLET_ENG_WEB_CH07.pdf

World Bank. (2016) Migration and Remittances Factbook 2016: Third Edition, World Bank. https://openknowledge.worldbank.org/handle/10986/23743 